\title{
Value Added From Money Managers in Private Markets? An Examination of Pension Fund Investments in Real Estate*
}

\author{
Aleksandar Andonov \\ Maastricht University \\ Piet Eichholtz \\ Maastricht University \\ Nils Kok \\ Maastricht University
}

\section{February 2012}

First draft - Please do not quote or distribute without authors' permission

\begin{abstract}
Real estate is the most important alternative asset class for pension funds and represents on average more than five percent of their total holdings. We employ a previously unexplored international database to examine the investments of some 880 pension funds in direct real estate and REITs over the 1990-2009 period. We document that larger funds are more likely to invest in real estate internally, have lower costs, and higher returns. Smaller funds are more likely to invest in direct real estate, through external managers and fund-of-funds, but largely ignore REITs. This significantly increases their costs and reduces their returns. Moreover, U.S. pension funds' investment costs are twice as high as those of their foreign peers, and their gross and net performance is lower. The underperformance of U.S. pension funds in real estate investments is most striking in the last two years of the sample period, which may be due to opportunistic investment behavior pre-crisis.
\end{abstract}

JEL classification: G11, G20, G23.

Keywords: pension funds, real estate, delegated investment management, economies of scale, performance, costs

\footnotetext{
${ }^{*}$ Contact authors via email at a.andonov@maastrichtuniversity.nl, p.eichholtz@maastrichtuniversity.nl and n.kok@maastrichtuniversity.nl. We thank CEM Benchmarking Inc. in Toronto for providing us with the CEM database. For helpful comments and suggestions, we thank Keith Ambachtsheer, Rob Bauer, Martijn Cremers, Bill Maher, Paige Muealler and David Watkins. We gratefully acknowledge a research funding provided by the Real Estate Research Institute (RERI), and by the Rotman International Centre for Pension Management at the Rotman School of Management, University of Toronto (ICPM). Kok is supported by a VENI grant from the Dutch Organization for Scientific Research (NWO).
} 


\section{Introduction}

Real estate is the most important alternative asset class in the portfolio of institutional investors. A recent survey of the Pension Real Estate Association (PREA), covering some $\$ 2.4$ trillion in assets under management, finds that real estate holdings represent about ten percent of the total assets of the surveyed fiduciary managers. Indeed, all properties in the NCREIF Property Index, which had a market capitalization of $\$ 273$ billion as of January 1, 2012, have been acquired, at least in part, on behalf of tax-exempt institutional investors - the great majority being pension funds. And according to Bond and Mitchell (2010), pension funds constitute more than 60 percent of the investors in the IPD UK database, the most prevalent database of commercial real estate investment properties, during the 1987-2006 period. Yet, remarkably little is known about the determinants of variations in real estate allocations, and, more importantly, about the performance of the real estate investments of pension funds and their managers. Assets allocated to real estate have grown substantially over the past decade, increasingly driven by the growing size and importance of institutional investors, but performance has been volatile. According to Pensions \& Investments' annual survey, worldwide real estate assets under management by tax-exempted institutions peaked in June 2008 at $\$ 1$ trillion and plunged to $\$ 677$ billion in June 2010. Pension funds generated much of the decline by greater allocation to opportunistic and value-added strategies and increased usage of leverage. ${ }^{1}$ This widely publicized undeperformance has led to discussion on the speculative behavior of what are supposed to be long-term, conservative fiduciary managers of tax-exempt pension plans.

Thus far, academic research has focused predominantly on the real estate asset allocation of institutional investors. Much has been written about the mixed-asset portfolio characteristics of real estate equities. Compared to the typical portfolio model predictions of about 10-20 percent allocations to real estate, ${ }^{2}$ institutional investors generally have fairly modest allocations to private and public real estate equities. It has also been documented that pension funds prefer investing in direct real estate to listed real estate investment trusts (REITs), even though the return characteristics are not different between the two types of investments after controlling for leverage, property-mix and appraisal smoothing (Pagliari, Scherer, and Monopoli (2005)). Lagged institutional investment flows significantly influence subsequent returns in private commercial real estate (Fisher, Ling, and Naranjo (2009), but capital flows do not influence subsequent returns in the REIT sector (Ling and Naranjo (2006)). The literature has been quiet on the performance of real estate mandates of institutional investors, as opposed to the recent attention to the performance of private equity mandates, another asset class characterized by illiquidity and a seemingly inefficient market, but accounting for a lower allocation of pension fund wealth. ${ }^{3}$

\footnotetext{
${ }^{1}$ See, for example, Pension Real Estate Association (PREA) Investor Report 2010.

${ }^{2}$ See for example: Friedman (1971), Webb and Rubens (1987), Webb (1990), Ennis and Burik (1991), Kallberg, Liu, and Greig (1996) and Hudson-Wilson, Gordon, Fabozzi, Anson, and Giliberto (2005).

${ }^{3}$ For private equity investments, Lerner, Schoar, and Wongsunwai (2007) analyze whether there exist systematic
} 
This paper is the first to investigate the investment behavior, costs and performance of pension funds in real estate investments, addressing a number of important and unresolved questions. First, which pension funds decide to invest in real estate? Second, when deciding to allocate capital to real estate, do pension funds invest in direct (private) real estate or in public (listed) real estate? And do pension funds internally select properties or REITs, or outsource this responsibility to external managers and even fund-of-funds? Third, what is the effect of the chosen investment subcategory and approach on investment costs and performance? And finally, do (dis)economies of scale and persistence effects play a role in the answers to these questions?

In this paper, we employ data on a large cross-section of pension fund real estate investors to shed light on these issues. We use the CEM dataset, the broadest global database on pension fund investments, comprised of a total of 884 U.S., Canadian, European and Australian/New Zealand pension funds for the period 1990-2009. Overall, assets under management of these funds exceeded $\$ 4.6$ trillion in 2009. CEM collects data from pension funds investing in multiple asset classes and the data has been used previously by French (2008) to study the cost of active investing, and by Andonov, Bauer, and Cremers (2011) to examine the asset allocation, market timing and security selection skills of pension funds. Other papers studying pension fund performance using the CEM database are Bauer, Cremers, and Frehen (2010) and Dyck and Pomorski (2011).

In this paper we focus solely on the real estate holdings of pension funds. For real estate investments, the database includes detailed information on each fund's target and actual real estate allocations, selfdeclared benchmarks for each real estate subcategory, and the precise cost structure and performance for all separate asset classes. ${ }^{4}$ The CEM database provides extensive coverage of both direct real estate investments and REIT holdings. For instance, the aggregate pension fund holdings in private commercial real estate covered in the database were more than $\$ 240$ billion in 2009 , which almost equals the total market value of the NCREIF Property Index. REIT holdings of pension funds covered by CEM in 2009 equal some $\$ 74$ billion, which corresponds to 32 percent of the FTSE Composite REIT Index market capitalization in 2009.

The CEM database provides a broad and complete perspective on the choices and outcomes of pension funds' real estate allocations. Using data at the pension fund level rather than real-estate-only datasets (like NCREIF, IPD, or NAREIT) provides a unique perspective on the costs and returns of real estate investors. ${ }^{5}$ First, the data incorporates returns in both public and private real estate investments, taking into account the time trend in weights assigned to both subcategories. Focusing on either

differences in the returns and investment strategies across several different classes of institutional investors (limited partners), e.g. banks, corporate and public pension funds, endowments, advisors, and insurance companies. See also Kaplan and Schoar (2005) and Phalippou and Gottschalg (2009) for analysis of private equity fund performance.

${ }^{4}$ Andonov, Bauer, and Cremers (2011) and Bauer, Cremers, and Frehen (2010) test the potential self-reporting bias in the CEM database and find that it does not seem to suffer from self-reporting with respect to total pension fund costs and returns, but larger pension funds are more likely to survive.

${ }^{5}$ See for example Bond and Mitchell (2010), Brounen, Eichholtz, and Ling (2007) for performance studies based on these datasets. 
NCREIF or NAREIT data does not reflect the overall real estate portfolio of an institutional investor, and does not provide insight in all allocation choices that institutional investors face within their real estate portfolio. Second, pension fund returns reflect the cost of real-life constraints involved in real estate investments, such as commitment periods and delays on the withdrawal of capital that external parties impose. Third, pension fund returns reflect the costs of managing a portfolio of underlying real estate investments in private, public or both real estate subcategories, as they are reported net of an additional layer of fees. Finally, we can also analyze the characteristics that determine whether an institution invests in real estate or not, as our dataset also includes information on pension funds that do not invest in real estate. This would not be possible if data from real-estate-only data vendors would be employed.

We document that around 75 percent of the pension funds in the CEM database invest in real estate. Real estate is the most important asset class after equity and bonds, and represents 5.36 percent of fund assets, on average. Two characteristics influence the probability whether a pension fund invests in real estate or not. First, larger pension funds are more likely to invest in real estate. A one unit increase in the log of assets increases the probability that a fund invests in real estate by 7.8 percent. Second, funds that allocate a higher percentage of their assets to other alternative asset classes are also more likely to incorporate real estate in their portfolio. A 10 percent increase in the allocation to other alternatives increases the probability of investing in real estate by 14 percent. Hence, pension funds appear to choose whether to invest or not in alternative asset classes, and subsequently decide to allocate part of these investments to real estate. Once a fund decides to invest in alternatives, real estate is likely to be part of a broader portfolio mix of alternative asset investments.

If a pension fund decides to invest in real estate it has to make two choices. First, funds select the investment subcategory. Although REITs provide easy and low-scale property exposure, which seems to make them attractive to smaller investors, the larger funds are in fact more likely to invest in REITs. We find that allocations to REITs are implemented as complementary investments to the direct real estate holdings of larger funds. In line with our results, Ciochetti, Craft, and Shilling (2002) also document that the largest pension plans invest more in REITs. ${ }^{6}$ Moreover, we find that funds with higher exposure to other alternative assets (funds seeking greater risk exposure) are more likely to opt for direct real estate, but have the same probability to invest in REITs. Second, pension funds decide what kind of investment approach to implement. Funds employ three main investment approaches: internal management, external management and investing through fund-of-funds. Larger pension funds are more likely to invest internally, whereas smaller funds are more likely to invest externally and through fund-of-funds. Internal management requires a long-term commitment of significant resources

\footnotetext{
${ }^{6}$ Using a large cross-sectional data with many small institutional investors, Ciochetti, Craft, and Shilling (2002) actually find a U-shape relation between REIT holdings and plan size. Institutions with very low wealth, which our data does not capture, choose to invest in REIT stocks. But as plan size increases, more investors choose to invest in direct real estate equities. Thus, their REIT holdings decrease with plan size. However, beyond some point, the pattern changes, with largest investors choosing to invest more in REIT stocks.
} 
to establish an internal real estate management department or an "at-arms-length" operating division, and is therefore more suitable for larger funds. However, even among the largest quintile of pension funds (with $\$ 33$ billion in assets under management on average) only around 42 percent of the funds manage property or REIT portfolios internally, whereas among the smallest quintile ( $\$ 336$ million in assets under management) only some 13 percent of the funds decide to invest internally. Establishing an internal department for direct selection of properties or REITs is costly and can be regarded as a more long-term approach. In line with this finding, we observe that funds with greater allocation to other alternative asset classes are more likely to invest externally in real estate. This positive relation implies that especially external real estate mandates are part of a broader portfolio of alternatives. Hence, when a fund decides to invest internally in real estate, it is more likely to specialize for a longer period in real estate, rather than invest in a broader portfolio of alternative assets, including hedge funds and private equity.

We then examine the effect of the real estate investment choices on costs and performance. Pension funds exhibit investment costs of 76 basis points for investing in real estate, which are higher for direct real estate ( 83 basis points) and lower for REITs (41 basis points). Even though our cost figures do not include the performance fees (which are subtracted directly from returns in the CEM database), real estate investment costs are significantly lower than private equity and hedge fund costs. Phalippou (2009) estimates that the average private equity buyout fund charges more than 7 percent fees per year (the annual management fee is 2 percent of capital commitments). For hedge funds, French (2008) documents that the average annual hedge fund fee for 1996-2007 is 4.26 percent of assets (the management fee alone is 1.16 percent), and, because they pay two layers of fees, the average for clients who buy through funds of hedge funds is even higher: 6.52 percent per year, with a top layer management fee of the fund-of-funds of 1.10 percent. $^{7}$

We find strong economies of scale in the costs of real estate investments: a one unit increase in the log of real estate holdings reduces the costs by 32 basis points. On the other hand, greater external management and allocation to fund-of-funds considerably increase the overall investment costs. Switching from internal management to complete external management results in a 21 basis point increase in investment costs. A switch to fund-of-funds increases the costs even by 122 basis points. Surprisingly, even after controlling for size and investment approach, we find that U.S. pension funds have 41 basis points higher costs as compared to funds from other regions, which can be mainly attributed to their higher costs for external mandates in direct real estate. In line with this finding, Andonov, Bauer, and Cremers (2011) document that Canadian pension funds have lower costs compared to U.S. funds when investing in equity, fixed income, cash, and private equity, even though Canadian funds are much smaller. ${ }^{8}$

\footnotetext{
${ }^{7}$ Andonov, Bauer, and Cremers (2011) also document higher fees for hedge fund and private equity investments compared to real estate investments among the U.S. and Canadian pension funds.

${ }^{8}$ Andonov, Bauer, and Cremers (2011) estimate that the total investment costs of U.S. pension funds are on average
} 
Regarding performance, we find that pension funds meet the thresholds of their benchmarks, the only exception being the underperformance of U.S. funds. In line with our results, using data on publicly traded REIT portfolios as well as portfolios of private entities, Hochberg and Mühlhofer (2011) find that, on average, both public and private real estate portfolio managers do not exhibit market timing or security selection skills. Our results suggest that the average underperformance of U.S. funds, which is about 143 basis points annually in direct real estate, may be largely due to the use of leverage in the years preceding and during the financial crisis of 2008 and 2009. Increased leverage may explain the modest outperformance during the 2005-2007 period, in which market returns were positive, and the substantial strong underperformance in the subsequent down market of 2008-2009. Another reason for this performance pattern may be found in exuberant choices for more opportunistic property types and speculative investments, like raw land property development projects.

The results on fund characteristics indicate that larger funds obtain higher returns: a one unit increase in the log of real estate holdings increases the returns by 32 basis points. We observe these economies of scale among both REIT and direct real estate investments. Part of the documented economies of scale can be explained by lower costs, since we also find that higher costs reduce performance, but the size effect remains strong and significant even after controlling for costs and investment approach. Investment approach has an even greater effect on performance. Even when controlling for size and costs, switching from internal to complete external management results in a 102 basis points decrease in returns. Moreover, investing via fund-of-funds results in 202 basis points lower returns. External management in real estate investments not only increases costs, but also leads to underperformance.

Finally, we examine persistence in the performance of pension fund real estate investments, using annual quintile rankings. We find some evidence that a selection of pension funds is persistently outperforming their direct benchmarks, but this finding does not hold for investors in REITs. In direct real estate, pension funds are more likely to end up in a better performing quintile next year, if they also performed well this year, and they are more likely to perform worse in the ranking next year, if they performed relatively poorly this year.

The remainder of this paper is organized as follows. The next section describes the institutional marketplace. Section 3 introduces the data. Section 4 investigates the choices pension funds make in their real estate investments, and addresses the internal versus external investments, the use of fund-of-funds and REITs, and the pension fund characteristics related to these choices. Section 5 studies the investment costs that pension face when choosing different investment approaches in real estate. Section 6 focuses on the performance of the real estate holdings, investigating the relation between benchmark-adjusted returns of pension funds and their investment choices and size, and determining performance persistence. The paper ends with a conclusion and discussion.

35.25 basis points per year, whereas Canadian funds exhibit costs of 25.65 basis points. 


\section{How tax-exempt money managers invest in real estate}

In this section we explain the institutional marketplace and the investment process followed by most pension funds when they are interested in allocating assets to real estate. Figure 1 presents a stylized scheme of the decision process and agency layers that institutional investors face when investing in real estate.

The first decision is whether a pension fund or other investor wants to include real estate in its asset allocation. According to institutional investors, the main reasons to add real estate to their portfolios are: (1) diversification and reduction of the overall risk of the portfolio; (2) hedging against inflation; (3) delivering steady cash flows to the portfolio (i.e., rents). Within the mean-variance framework Hudson-Wilson, Gordon, Fabozzi, Anson, and Giliberto (2005) find that real estate fulfills most of the investors' expectations, even though some other studies (Brounen, Prado, and Verbeek (2010) and Chun, Ciochetti, and Shilling (2000)) conclude the contrary when accounting for pension fund liability obligations.

The second decision is to choose how to invest in real estate. Institutional investors seeking exposure to real estate can invest in debt-type assets and equity-type assets. Debt-type assets include private commercial real estate debt (whole loans or mortgages) and commercial mortgage-backed securities. The debt real estate assets are usually part of a broader fixed income portfolio and are not the focus of this paper. Our analysis covers the equity real estate assets, which are organized as separate mandates in the pension fund portfolio. There are two subcategories of equity real estate assets: (1) direct (private) commercial real estate and (2) listed (public) real estate equity, in many countries structured as real estate investment trusts (REITs), or an equivalent legal structure.

After deciding to invest directly or through REITs, a pension fund selects an investment approach. Investing in direct (private) real estate can be done internally or outsourced to third-party fund managers. If a pension fund decides to invest internally in direct real estate it usually establishes a separate or "at-arms-length" division. ${ }^{9}$ When outsourcing, pension funds can select directly the external managers (funds) or invest their assets via fund-of-funds. ${ }^{10}$ In the last case the fund-of-fund selects the external managers (funds), who then select the assets.

Investing in public real estate requires selection of REITs, which can be outsourced to external money managers or can be executed internally by the pension fund. REIT investments can also be classified as passive if they replicate a broad capital market benchmark (e.g., NAREIT) or are dedicated to matching a specific set of liabilities (i.e., if REIT investments are part of a strategic asset allocation designed to match fund-specific liabilities). However, the vast majority of pension funds

\footnotetext{
${ }^{9}$ Internal investing means that the buy-sell decisions for the individual properties are made within the organization (including wholly-owned subsidiaries).

${ }^{10}$ External investing also incorporates real estate limited partnerships. The limited partnerships are investments in real estate funds which focus on active management of properties, ranging from moderate reposition or releasing of properties to development or extensive redevelopment. These funds typically have a fixed life span during which properties are acquired, actively managed and then sold. This category includes value added and opportunistic partnerships.
} 
investing in public real estate allocate their assets to active mandates, which usually do not implement buy-and-hold strategies when selecting REITs.

Overall, only when investing internally in direct real estate does a pension fund directly select properties. External investing in direct real estate and REIT investments create additional agency layers between the pension fund and the properties. Figure 1 presents these additional agency layers. The existence of third-party organizations creates potential agency conflicts and increases the investment costs because every additional layer adds new fees. However, not all delegating investment approaches create similar agency conflicts. REITs are listed on the stock market, which not only increases their liquidity and lowers the investment costs, but also reduces the agency conflicts. Additionally, Bauer, Eichholtz, and Kok (2010) show that REITs' institutional design reduces agency conflicts. On the other hand, external investing in direct real estate demands strong monitoring capacity from the pension fund because the stock market does not mitigate potential agency conflicts. Moreover, the costs for external investments in private real estate are higher because these incorporate management fees and performance fees. Investing through fund-of-funds adds one additional layer of both management and performance fees. Hence, when investing in real estate, pension funds need more skills compared to equity and fixed income investments to monitor the external parties, especially in direct real estate.

\section{Data}

We use the defined benefit (DB) pension fund data collected by CEM Benchmarking Inc. (henceforth CEM). Pension funds included in the CEM database cover a substantial share of global pension fund assets under management. Over the 1990-2009 period, Canadian pension funds included in CEM database held approximately 80-90 percent of the total assets under management by Canadian pension funds. Over the same period, the U.S. funds included in the dataset controlled around 30-40 percent of the total assets under management by the U.S. pension fund sector. The CEM database also covers a smaller percentage of European, Australian and New Zealand pension funds, mostly relatively large funds. Table 1 presents the number of funds in the CEM database, the number of funds investing in real estate per region and the average size of these pension funds in US\$ billion. Pension funds covered by the CEM database had on average more than $\$ 13$ billion of assets under management in 2009 . To our knowledge, this is the broadest global database on pension fund asset allocation and performance available for academic research.

The CEM database contains detailed information on each fund's target and actual asset allocation decisions, self-declared benchmarks for each asset class, and precise cost structure and performance for all separate asset classes and their benchmarks. While CEM collects data from pension funds investing in multiple asset classes, we solely focus on the real estate holdings in this paper. In the data, real estate includes assets invested in direct real estate holdings, segregated real estate holdings, real 
estate limited partnerships and real estate investment trusts (REITs). REIT investments are reported separately in the CEM database, not as part of a small cap equity mandate.

As reporting to CEM is voluntary, the data is potentially vulnerable to self-reporting bias. Andonov, Bauer, and Cremers (2011) address the self-reporting problem by constructing a Cox proportional hazard model. The authors test whether the decision of a particular fund to exit the database is related to its returns (from all asset classes), costs or size. The results show that the database does not suffer from self-reporting bias with respect to costs and returns, though larger funds are more likely to survive in the CEM database. Bauer, Cremers, and Frehen (2010) address the self-reporting bias by matching the CEM data with the Compustat SFAS data and test whether the decision to stop reporting is related to the overall fund performance. Their results indicate that there is no evidence of a self-reporting bias related to performance in the exiting and entering years.

Table 1 shows that, on average, 75 percent of the pension funds in the CEM database invest in real estate. Panel A of Figure 2 shows that the percentage of funds investing in real estate is stable over time, fluctuating around 70-80 percent. In Europe and Australia/New Zealand this percentage is higher because the database covers few large funds. In Canada the percentage of funds investing in real estate decreases over time, from 75 percent in 1990 to 60 percent in 2009.

During the 1990-2009 period, pension funds real estate holdings increased substantially. As Panel B in Figure 2 shows, the total value of pension fund real estate investments amounted to more than $\$ 320$ billion in 2009 (\$370 billion in 2008). In line with Pagliari, Scherer, and Monopoli (2005) pension funds favor private real estate investments over REITs. In 2009, pension fund holdings in direct real estate are more than $\$ 240$ billion (in 2008 they were more than $\$ 275$ billion), which is almost equal to the total market value of the NCREIF Property Index in these years. However, the dominance of private-market holdings decreases over time, and in 2009 the REIT holdings of pension funds are equal to $\$ 74$ billion ( $\$ 85$ billion in 2008 ). These REIT holdings correspond to 32 percent of the FTSE Composite REIT Index market capitalization in 2009 (33 percent in 2008). A minor part of pension funds' real estate holdings is classified as "other real assets". ${ }^{11}$

Real estate represents on average 5.36 percent of pension fund assets. Panel C of Figure 2 presents the trend in real estate assets as a percentage of pension fund total assets under management. Real estate allocations were higher at the beginning of the sample period (1990-1992) and they picked up again in 2008, when real estate investments were 7.6 percent of the total assets. Panel A of Table 2 also shows that there is substantial variation in the percentage allocation to real estate, with an overall standard deviation of 3.71 percent. European and Australian/New Zealand funds allocate a larger share of their assets to real estate. Panel B of Table 2 confirms that European and Australian/New Zealand funds have very large mandates in real estate, on average. Their $25^{\text {th }}$ percentile allocation to

\footnotetext{
${ }^{11}$ Other real assets subcategory captures investments which could not be classified as direct real estate or REITs. For instance, a building owned by the pension fund and used as office space by the fund, but also partially leased to other tenants for a rent, will be classified here. Other real assets also capture investments in raw land.
} 
real estate is substantially larger than the median size of U.S. and Canadian funds.

In Panel $\mathrm{C}$ of Table 2 we observe the size of the real estate investments by subcategory. The size of REIT mandates is comparable to the size of direct real estate mandates, although the number of funds investing in REITs is substantially lower. Figure 3 provides graphs of the percentage of funds investing in REITs and direct real estate. Panels A and B of Figure 3 show that the percentage of funds investing in direct real estate is always higher than the percentage of funds investing in REITs. Direct real estate represents a major part of pension fund holdings, although during the 1990-2009 period, REITs gained in popularity, especially since 1998. Figure 4 Panel A shows that, over time, pension funds keep most of their investments in direct real estate, while the REIT mandates do not exceed 20 percent of the holdings.

Pension funds implement three main investment approaches within their real estate allocation: internal management, external management and investing in fund-of-funds. Internal investing in real estate means that the buy-sell decisions for the underlying assets are made within the pension fund (including wholly-owned subsidiaries). Funds investing via external management leave the buy-sell decisions to third-party fund managers. Investing in fund-of-funds refers to investing in funds whose holdings primarily consist of other funds. While internal and external mandates exist in pension funds' portfolios during the entire sample period, fund-of-funds show up for the first time in 1995 and expanded especially in the last three years (since 2007).

Panel D of Table 2 shows that the average internal mandate is much larger than the external mandate, which implies that mainly larger pension funds decide to invest internally in real estate. The vast majority of funds implement external management. In Figure 4 Panel B we observe that, on average, pension funds manage some 80 percent of their assets externally, with little variation over time. More surprising is that the allocation to internal mandates decreases from 22 percent in 1990 to 16 percent in 2009 due to an increased allocation to fund-of-funds. Hence, the percentage allocation to fund-of-funds increases to 5.3 percent in 2009 (6 percent among U.S. funds) mainly at the expense of internal, not external mandates. In Table 3 Panel A we show that pension funds are more likely to invest internally in REITs rather than in direct real estate. The average allocation to internal mandates is 45 percent among REITs versus 17 percent among direct real estate investments. Panel B of Table 3 presents that the percentage of internal management is lowest among U.S. funds (7.62 percent). Canadian funds, which are significantly smaller than U.S. pension funds, allocate 35.62 percent of their real estate investments to internal mandates. European and Australian / New Zealand funds also allocate more to internal mandates. Investments in fund-of-funds are mainly implemented by U.S. and European funds.

Passive management in real estate is not really possible, except when it is held through REITs. In direct real estate Fisher and Goetzmann (2005) show that portfolio returns vary substantially because of individual property differences and the timing of investments, even for portfolios of more than 100 
properties. Hence, in direct real estate, larger pools of properties are required to achieve returns similar to the returns of the population of commercial properties (e.g., NCREIF Property Index). So, one could expect that a significant part of the REIT holdings are managed passively. This, however, is not the case. Investments are classified as passive in the data, if they replicate a broad capital market benchmark (like NAREIT) or match a specific set of liabilities, i.e., if they are part of a strategic asset allocation designed based on the pension fund liabilities. On the basis of that definition, most of the REIT investments are managed actively (94 percent) and there are very few funds investing passively in REITs.

\section{Pension fund characteristics and real estate investments}

In this section we analyze the two main decisions presented in Figure 1. First, we investigate which pension fund characteristics influence the decision to invest in real estate. Second, for the institutional investors with an existing real estate allocation, we examine how they invest: which subcategories of real estate the investors choose, and which investment approach they implement. To answer these questions we use a binary response logit model:

$$
\operatorname{Pr}\left(y_{i, t}\right)=f\left(\text { FundSize }_{i, t}+\text { Alternatives }_{i, t}+\text { PlanType }_{i}+\text { Region }_{i}+\text { YearDummies }_{t}\right)
$$

where $f$ is a logit function taking on values strictly between zero and one, and $y_{i, t}$ is a binary dependent variable. For example, in the first case the dependent binary variable $y_{i, t}$ is 0 if a fund $i$ does not have any real estate holdings in year $t$ and 1 otherwise. We model the probabilities as a function of pension fund characteristics, focusing on total fund size (FundSize) and the allocation to other alternative asset classes (Alternatives) of fund $i$ in year $t$. FundSize is the log of the US\$ value of the pension fund assets under management. The Alternatives variable captures the strategic asset allocation to private equity, hedge funds, infrastructure, tactical asset allocation mandates, commodities and natural resources. We also control for plan type, i.e., whether the pension plan is public, corporate or other. Lastly, we control for regional effects and include year dummies. We cluster the standard errors by pension funds, allowing for intragroup correlation.

In Models 1 and 2 of Table 4 Panel A we document that funds which allocate a higher percentage of their assets to other alternative asset classes are also more likely to invest in real estate. For example, the probability to invest in real estate for funds which have no allocation to other alternative assets is 70.48 percent. This probability increases to 83.83 percent for funds that have 10 percent of assets allocated to other alternative asset classes. The marginal coefficient on allocations to alternatives estimated at means also shows that a 10 percent increase in the allocation to alternatives increases the probability of investing in real estate by 14 percent. Hence, our results suggest that pension funds tend to choose whether or not to invest in alternative asset classes, besides fixed income and public equities, 
rather than directly choosing to invest in real estate. Once a fund decides to invest in alternatives, real estate is likely to be part of a broader portfolio that also incorporates hedge funds, private equity and other alternatives. This result remains significant after controlling for regional and plan type effects. Interestingly, the region dummy variables are not significant, which implies that pension funds from all countries have similar probabilities to invest in real estate.

Furthermore, our results also indicate that larger institutional investors are more likely to invest in real estate. A one unit increase in the logarithm of assets under management (i.e., doubling the fund size) increases the probability that a pension fund invests in real estate by 7.8 percent. Additionally, in Table 4 Panel B we split the funds into quintiles based on their size. In the smallest quintile (on average $\$ 336$ million asset under management) 51 percent of the funds do not invest in real estate. This percentage decreases as we move to the largest quintile (on average $\$ 33$ billion assets under management). However, even in the largest quintile, 9 percent of the funds do not invest in real estate. Overall, we find that larger funds are more likely to invest in real estate. In addition, the decision to invest in real estate is part of a larger overall decision to invest in alternative assets.

In Models 3-6 of Table 4 Panel A we then analyze which characteristics determine whether a pension fund invests in direct real estate or REITs. In the logit regressions we only include pension funds with real estate holdings. In specifications 3-4 the dependent binary variable is 0 if a fund does not have any REIT holdings and 1 otherwise. In specifications 5-6 the dependent variable is based on the direct real estate holdings.

Interestingly, although REITs provide easy and low-scale property exposure, which should make them attractive to smaller investors, larger funds are more likely to invest in REITs. A one unit increase in the logarithm of asset under management increases the probability that a pension fund invests in REITs by 4.2 percent. European funds are more likely to invest in REITs than their U.S. counter-parts, whereas Canadian funds are less likely to invest in REITs. For direct real estate, we do not find a relation between size and the decision to invest. However, funds with higher allocation to other alternatives have a higher probability to invest in real estate directly. For example, the probability to invest in real estate for funds that have no allocation to other alternative assets is 92 percent. This probability increases to 95 percent for funds that have at least 10 percent of assets allocated to other alternative asset classes. Pension funds with higher exposure to alternative assets are more likely to opt for direct real estate, but have the same probability as other funds to invest in REITs.

The probability to invest in direct real estate given that a pension fund decides to invest in real estate is close to 100 percent. This implies that REITs are usually incorporated in a portfolio of pension funds as complementary investments to existing exposure to direct real estate. Panel B of Table 4 shows that across all size quintiles the percentage of funds investing only in REITs but not in direct real estate is very low. Surprisingly, the largest quintile (\$33 billion of assets) has the highest percentage of funds investing in REITs only ( 8 percent). Among the pension funds that are in the 
smallest quintile ( $\$ 336$ million of assets), 42 percent invest in private real estate only, while just 2 percent invest in REITs but not in direct real estate. Most of the REIT investments are done by larger funds as a complementary investments to their direct real estate holdings. The percentage of funds investing simultaneously in both REITs and direct real estate is always higher than the percentage of funds investing only in REITs, and increases as we move from the smallest (3 percent) to the largest quintile (29 percent).

Summarizing, smaller funds are less likely to invest in REITs, but not in direct real estate. This finding is surprising since investing in private real estate is more expensive, less liquid and requires more monitoring skills, because it has a higher potential for agency conflicts, suffering from asymmetric information problem. Additionally, institutional investors with greater allocation to other alternative assets are more likely to invest in direct real estate, which means that they simultaneously monitor investments in multiple alternative asset classes.

Table 5 Panel A presents the results of further analysis of the characteristics that determine whether a pension fund invests internally, externally or via fund-of-funds. In the logit regressions we include only pension funds with real estate holdings. In specifications 1-2 the dependent binary variable is 0 if a fund does not invest internally and 1 otherwise. In specifications 3-4 and 5-6 the dependent variable reflects external management and fund-of-funds investments, respectively.

As expected, larger funds are more likely to invest internally. A one unit increase in the logarithm of asset under management (i.e., doubling the portfolio size) increases the probability that a pension fund invests internally by 10 percent. On the other hand, smaller funds are more likely to invest externally and through fund-of-funds. A one unit increase in the log size decreases the probability that a pension fund invests externally by 2.6 percent. Furthermore, the allocation to other alternative assets is significantly and positively related to the probability to invest externally. For instance, the probability to invest externally for funds which have no allocation to other alternative assets is 87 percent. This probability increases to 92 percent for funds that have 10 percent of assets allocated to other alternative asset classes. The marginal effect of allocations to alternatives estimated at means also indicates that a 10 percent increase in the allocation to alternatives increases the probability of investing in real estate by 5.07 percent. In line with the descriptive statistics in Table 3 Panel A, funds with greater allocation to REITs have a higher probability to invest internally. Finally, even after controlling for size, investments in other alternative asset classes and allocation to REITs, the likelihood that Canadian and European funds invest internally is significantly higher as compared to U.S. funds.

Since pension funds can invest simultaneously via all three investment approaches or via two of them, Table 5 Panel B analyzes further the relation between size and investment approach. We split the funds again into quintiles based on their size and calculate the percentage of funds selecting a particular combination of investment approaches. The majority of funds across all size quintiles invest only 
externally in real estate. For instance, among the smaller quintiles more than 80 percent of the funds do so. Additionally, a larger fraction of funds in the smaller quintiles invests through fund-of-funds. As we move from the smallest ( $\$ 336$ million in assets) to the largest quintile ( $\$ 33$ billion in assets) the percentage of funds investing internally (only internally or simultaneously internally and externally) is increasing. However, even among the largest quintile, some 58 percent of the funds still do not internally manage properties or REITs.

Our results indicate that larger funds are more likely to invest internally, but a minority of the smallest funds also take that route. In the smallest quintile just over 13 percent of funds decide to invest internally. Internal management requires devotion of sufficient resources to establishing an internal real estate management department or an "at-arms-length" real estate operating division. Establishing an internal department for direct selection of properties or REITs is costly and can be regarded as a more long-term approach. In line with this conclusion, we observe that funds with a larger strategic allocation to other alternative asset classes are more likely to invest externally. This positive relation implies that external real estate mandates are part of a broader portfolio of alternatives. Hence, when a fund decides to invest internally in real estate, it is more likely to specialize for a longer period in real estate, rather than invest in a broader portfolio of alternatives.

\section{The cost of pension fund real estate investments}

In this section we analyze the overall level of real estate investment costs, the differences in costs between REITs and direct real estate, and the role of investment approaches and size as determinants of cost differences.

The CEM database contains detailed information on the real estate investment costs of pension funds. Internal investment costs include compensation and benefits of employees managing internal portfolios and support staff, related research expenses and allocated overhead costs. In the CEM database external investment costs capture the management fees paid to external parties. The performance fees, carried interest ${ }^{12}$ and rebates ${ }^{13}$ are directly subtracted from the returns and are not incorporated in the cost figures. External investments costs also include costs for internal staff whose sole responsibility is overseeing the external investments in real estate assets. Similarly, for fund-of-funds cost figures capture the base management fee paid to both the fund-of-funds manager and the underlying managers, but it does not include performance fees and carries interest on either layer.

Table 6 provides the summary statistics of total real estate investment costs per region. Pension funds face costs of around 76 basis points for investing in real estate. U.S. funds have higher investment costs than funds from other regions. The average costs of U.S. funds is 91 basis points, which is about

\footnotetext{
${ }^{12}$ Carried interest is a fee that is a portion of returns exceeding a hurdle rate.

${ }^{13}$ Rebates are the limited partners share of certain fee income realized by the general partner in connection with the fund, such as fees for break-up, monitoring and funding.
} 
twice the percentage their foreign peers are paying. Canadian funds pay 56 basis points, European funds 38 basis points and Australian / New Zealand funds pay 45 basis points for their real estate investments.

Figure 5 shows that U.S. funds have consistently higher costs during the entire sample period (1990-2009). Results in Panels B and C of Figure 5 show that U.S. pension funds have higher costs for investing in both REITs and direct real estate. The three panels of Figure 5 suggest that there are no time patterns in real estate investment costs. The slightly increasing costs in the 2007-2009 period are due to the greater allocation to fund-of-funds, which is the most expensive investment approach in real estate.

Costs summary statistics for subcategories are presented in Panel B of Table 6. The average costs for investing in direct real estate are 83 basis points and are about double the costs for investing in REITs (41 basis points). Internal investing in REITs and internal direct selection of properties are associated with substantially lower costs compared to the external investment approaches.

Furthermore, among private real estate investments, limited partnerships and fund-of-funds bear substantially higher costs as compared to other ways of gaining real estate exposure: 143 and 183 basis points, respectively. Panel $\mathrm{C}$ of Table 6 shows that costs for all external mandates together are 86 basis points compared to the 26 basis points of all internal mandates. ${ }^{14}$

Overall, the results indicate that the selected subcategories and the investment approach strongly influence the overall cost level. However, the non-parametric comparisons are of course not conclusive: for example, U.S. funds have lower a allocation to internal mandates (only 7.62 percent, on average) compared to funds from other regions, which may explain their higher costs. For more precise inferences, and to disentangle the effects of real estate portfolio size, allocation to subcategories and investment approach, we implement a regression analysis, using pooled panel regressions with year and regional or fund-fixed effects:

$$
y_{i, t}=\beta \text { Mandate }_{i, t}+\gamma \text { InvApproach }_{i, t}+\delta \text { YearDummies }_{t}+c_{i}+u_{i, t}, \quad t=1,2, \ldots, 20
$$

where $y_{i, t}$ refers to the investment costs, $c_{i}$ captures regional or fund-fixed effects and $u_{i, t}$ are idiosyncratic errors. Mandate is the $\log$ of the US $\$$ value of the real estate investment portfolio, InvApproach refers to the percentage allocation to external managers, fund of funds, etcetera.

Table 7 presents the results of costs regressions. Regressions for the pooled sample of all funds indicate that U.S. funds have costs that are 41 basis points higher as compared to pension funds from other regions, even when controlling for size and investment approach. We also document

\footnotetext{
${ }^{14}$ Costs for all external mandates are calculated as a weighted average of costs for external mandates in REITs, external mandates in direct real estate, limited partnerships in direct real estate and external mandates in other real assets. Costs for all internal mandates are also a weighted average of internal investment costs across all subcategories. Investments in direct real estate via fund-of-funds are the only category from Panel B not incorporated in Panel C, because we analyze the fund-of-funds as a separate investment approach.
} 
that pension funds which allocate more assets to real estate realize strong scale advantages in their investment costs. Looking at the entire sample, a one unit increase in the log of the value of real estate investments reduces the costs by some 32 basis points, even when controlling for investment approach, year and fund-fixed effects. Our results also indicate that allocations to external money managers and fund-of-funds increase the overall investment costs. Switching from internal management to complete external management results in a 21 basis points increase in the investment costs. A complete switch to fund-of-funds would increase the costs by some 122 basis points.

When we split the sample in regions, we still find strong economies of scale among U.S. and Canadian funds. For Europe and Australia/New Zealand, the log of real estate assets under management is not consistently significant, as the sample is smaller and funds are generally very large. (The size of the minimum allocation to real estate is equal to the median investment of U.S. and Canadian funds.) The observed scale advantages are much stronger among U.S. funds, where a one unit increase in the $\log$ real estate holdings reduces the costs by 42 basis points. Among Canadian funds there are also economies of scale in costs, but a one unit increase in the log real estate assets reduces the costs just by 11 basis points. Greater allocation to external mandates and fund-of-funds remain positively related to costs in the regressions by region with year and fund-fixed effects.

In Panel B of Table 7 we investigate the importance of size and investment approach in explaining the costs per real estate subcategory. In the regressions with region and year-fixed effects, the size coefficient is significantly negatively related to investment costs across both subcategories (REITs and direct real estate). Controlling for investment approach also explains part of the cross-sectional variation in investment costs. The percentage of assets managed externally are positively related to the costs associated with REIT investment. Similarly, the percentage of assets invested in external mandates, fund-of-funds and limited partnerships result in substantially higher costs for direct real estate investments.

Adding fund-fixed effects removes considerable variation, as indicated by the much higher $\mathrm{R}^{2}$, i.e., the amount of fund investments in real estate subcategories does not vary strongly over time, especially relative to the large cross-sectional variation in size. Thus, the coefficient for log Mandate becomes insignificant for REITs and less significant for direct real assets investment costs. However, when analyzing the total real estate investments at the fund level, the coefficient on size remains consistently significant (see Panel A).

Results in Table 7 Panel $\mathrm{C}$ show that larger funds have lower costs also within internal, external and fund-of-funds investments. The magnitude of the costs economies of scale is much stronger for external mandates, where one unit increase in the log of assets managed externally reduces the costs by 35 basis points. For internal costs, a one unit increase in the log of assets managed internally reduces the internal costs by 7 basis points. Hence, larger funds can not only organize internal mandates more efficiently, but also negotiate lower fees for their external investments in real estate. This points at 
"bargaining power" with external money managers. When analyzing the costs of fund-of-funds, the Mandate variable is not significant once we control for fund-fixed effects, because the number of funds investing in fund-of-funds is low and the fund-fixed effects capture this relation.

Even after controlling for mandate size and investment approach, we find that U.S. pension funds have significantly higher costs. The U.S. dummy variable is significant and equals 41 basis points, which is the difference in costs between U.S. pension funds and institutional investors from other regions investing in real estate. Results in Panel C indicate that the higher costs of U.S. funds can be mainly attributed to their external mandates, whereas their costs for internal investing are similar to the costs of pension funds from other regions. In addition, the results in Panel B suggest that U.S. funds overpay mainly for their mandates in direct real estate. The higher costs of U.S. funds for external investments in direct real estate could be due to a worse relative negotiating position of U.S. funds, as the vast majority of the pension funds do not consider the option to invest internally, i.e., to select properties, and rather use external money managers. (One would expect that greater attention to internal management increases the competitive pressure on the external real estate asset management industry.)

In conclusion, we document that pension funds allocating more assets to real estate realize strong scale advantages in their investment costs. On the other hand, greater external management and allocation to fund-of-funds considerably increase the overall cost of investment in real estate. U.S. pension funds have considerably higher costs for investing in real estate, even after controlling for mandate size and investment approach.

\section{Pension fund performance in real estate}

In the previous sections, we documented that pension funds prefer investing in direct real estate over REITs, and prefer external to internal management, despite the higher costs associated with these approaches. It may be possible that this preference is driven by performance differences in these approaches. In this section we examine whether the returns of pension funds in real estate can explain their preference for more expensive investment approaches. We first address the performance of allocations to REITs and direct real estate, after deducting the returns on self-reported benchmarks and the investment costs. Next, we relate these net benchmark-adjusted returns to the size of real estate assets and implemented investment approach. Finally, we investigate the persistence in pension fund real estate investment performance.

\subsection{Benchmark-adjusted returns}

Table 8 reports the returns of pension funds in real estate by subcategory and investment approach. Panel A shows that the average gross return of pension funds in real estate during the 1990-2009 period 
is about 7 percent. REITs delivered a higher return (10.92 percent) compared to direct real estate (6.70 percent). Interestingly, the gross returns on internally managed assets (7.77 percent) are higher than the returns on external mandates (6.82 percent).

To put these returns into perspective, we compare them with the returns on self-reported benchmarks. In the CEM database, pension funds declare their benchmarks, which are usually market indexes (for example, the NCREIF or FTSE/NAREIT for U.S. real estate investments), against which asset class performance is measured. The realized returns and the benchmark returns are provided in the local currency. ${ }^{15}$ The advantage of using self-declared benchmarks is that these benchmarks more precisely represent the allocation and risk exposure of the real estate investments. For example, if a fund is exposed to office buildings in the U.S., benchmarking its returns against the NCREIF Office Index is better than using the broader NCREIF Property Index. Similarly, if a pension fund invests internationally and engages in any currency management, the benchmark returns are a weighted average of indices in multiple countries and account for the implemented hedging policy. The disadvantage is that pension funds can strategically select benchmarks which are easier to outperform, which implies that one should be careful when drawing conclusions if outperformance relative to these benchmarks would be documented.

Our results in Table 8 Panel B show that pension fund mostly match, but do not outperform, their self-declared benchmarks. In this panel we run a random coefficient regression with only a constant for returns on all real estate assets, returns by subcategory and returns by investment approach. An important advantage of the random coefficient model is that it allows for heteroskedasticity-adjusted and fund-specific betas, while being more robust to outliers than the standard Fama and MacBeth (1973) approach. Following Swamy (1970), the random coefficient model is similar to a generalized least squares approach that puts less weight on the return series of funds that are more volatile. In the regressions we include every pension fund that has at least 3 return observations. ${ }^{16}$ The overall gross benchmark-adjusted returns of all pension funds are not significantly different from zero. We do, however, observe outperformance in two cases. First, pension funds obtain positive abnormal annual returns of 108 basis points from their internally managed investments. Across all regions the benchmark-adjusted returns on internal investments are positive, and they are statistically significant for Canadian and European funds. Second, we observe positive and significant outperformance of 113 basis points per year among REIT investments. However, we cannot conclude that pension funds obtain alpha on a risk-adjusted basis, because our annual data does not allow to control for multiple benchmarks, which, according to Hartzell, Mühlhofer, and Titman (2010), explains a significant portion of REIT returns. ${ }^{17}$

\footnotetext{
${ }^{15}$ If currency risk hedging is done at the asset class level, pension funds provide hedged returns and benchmarks.

${ }^{16}$ Our results do not change if we use all funds in the sample regardless of the number of observations, nor if we use only funds with at least 5 observations.

${ }^{17}$ Hartzell, Mühlhofer, and Titman (2010) investigate three sets of REIT-based benchmarks, plus an index of returns derived from non-REIT real estate firms, namely homebuilders and real estate operating companies. The REIT-based
} 
Contrasting the pooled results, U.S. pension funds investing in fund-of-funds underperform their self-declared benchmarks by 208 basis points per year, even before deducting the investment costs. Part of this staggering underperformance is due to higher costs of fund-of-funds investments, because the CEM database captures only the management fees paid to both the fund-of-funds manager and the underlying managers. The costs data do not include the performance fees and carries interest paid on either layer, as these costs are deducted directly from the gross returns.

In Panel $\mathrm{C}$ of Table 8 we also deduct the investment costs and focus on the net benchmark-adjusted performance. The significant annual underperformance of 86 basis points among all funds is mostly driven by the underperformance of U.S. pension funds. The returns on investments in other regions are not significantly different from zero. However, U.S. funds significantly underperform their selfdeclared benchmarks in direct real estate by 143 basis points per year. Interestingly, U.S. funds do not underperform within their internal mandates, but only in their selection of external money managers (-129 basis points) and fund-of-funds (-376 basis points). This substantial underperformance cannot be explained solely by investment costs, because these are much lower than the estimated negative alphas.

We investigate further why U.S. pension funds underperformed their benchmarks. Figure 6 displays the gross returns of U.S. pension funds in direct real estate, the returns on the CEM self-declared benchmarks, the returns on the NCREIF Property Index, and the net benchmark-adjusted returns. Until 2004 the performance of U.S. funds in direct real estate was close to their benchmarks. In the period 2005-2007 U.S. pension funds obtained positive net benchmark-adjusted returns. However, in the last two years (2008-2009) U.S. funds experienced substantial underperformance in direct real estate. As Figure 6 shows, the net benchmark-adjusted returns in 2008 were -6.28 percent points. In 2009, the average return of U.S. pension funds in direct real estate was -29.24 percent points and they underperformed their self-declared benchmarks by 12.43 percent points. Hence, the average underperformance of U.S. funds of 143 basis points in direct real estate is to a large extent due to their underperformance during the financial crisis, which may be explained by increased usage of leverage in their direct real estate holdings during the 2005-2009 period. The increased usage of leverage resulted in modest outperformance in periods with positive market returns (2005-2007), but also substantial underperformance in the down-market of 2008-2009. We observe similar patterns among pension funds from other regions, ${ }^{18}$ but not as extreme as among the U.S. funds, whose investment choices in this regard seems to have been especially bad.

factors are a set of characteristic factors, a set of property-type factors and a set of statistical factors. Using annual return data we cannot control for these extensive list of factors.

${ }^{18}$ Canadian, European and Australizan/New Zealand funds also outperform their benchmarks in the 2005-2007 period and underperform disproportionally during the 2008-2009 period. 


\subsection{Performance and characteristics}

In this section, we relate the net benchmark-adjusted returns to certain characteristics of pension funds employing Fama and MacBeth (1973) regressions, while correcting for autocorrelation and heteroskedasticity using Newey-West standard errors. In the first stage, we regress the fund-specific net benchmark-adjusted returns on a set of characteristics for each sample year:

$$
R_{i, t}=\alpha_{t}+\beta_{t} \text { Mandate }_{i, t}+\gamma_{t} \text { Costs }_{i, t}+\delta_{t} \text { Inv Approach }_{i, t}+u_{i, t} \quad i=1,2, \ldots N \text { for each year } t .
$$

where $R_{i, t}$ refers to the net benchmark-adjusted returns of fund $i$ in year $t$ and $u_{i, t}$ is a a normally distributed zero-mean error term. Mandate is the log of the US\$ value of the real estate asset portfolio, Costs refers to the real estate investment costs in percentage points, and InvApproach refers to the percentage allocation to external managers, fund of funds, etcetera. In the second stage we estimate the coefficients as the average of the cross sectional regression estimates:

$$
\hat{\alpha}=\frac{1}{T} \sum_{t=1}^{T} \hat{\alpha}_{t} \quad \hat{\beta}=\frac{1}{T} \sum_{t=1}^{T} \hat{\beta}_{t} \quad \hat{\gamma}=\frac{1}{T} \sum_{t=1}^{T} \hat{\gamma}_{t} \quad \hat{\delta}=\frac{1}{T} \sum_{t=1}^{T} \hat{\delta}_{t}
$$

Results in Panel A of Table 9 show that real estate mandate size is positively related to performance. A one unit increase in the log of real estate holdings (Mandate) increases the net benchmark-adjusted returns by 43 basis points (see Model 1). The economies of scale are observed among U.S. and Canadian pension funds, but not among the European and Australian/New Zealand funds. This may be due to smaller sample sizes, and the fact that the latter samples mainly cover very large funds. Furthermore, we observe that higher costs reduce performance more than proportionally. An increase in costs by 100 basis points results in 155 basis points lower returns (see Model 2). The documented economies of scale and the negative relation between costs and performance remain even after controlling for investment approach. We observe in Model 3 that, when controlling for costs and investment approach, a one unit increase in the log real estate assets under management (Mandate) results in 32 basis points higher returns. In addition, investment costs still have a disproportionally negative effect on performance, especially among Canadian funds. This means that paying higher fees not only reduces returns, but also leads to worse gross performance. Our results also indicate that external management and fund-of-funds reduce performance. Switching from 100 percent internal management to complete external management results in a 102 basis point decrease in the net benchmark-adjusted returns. A complete switch to fund-of-funds would reduce the returns by 202 basis points.

In Panel $\mathrm{B}$ of Table 9 we examine the relation between performance in real estate subcategories and characteristics. In this panel, mandate size, costs and investment approach variables refer to REIT and direct real estate investments, respectively. For REITs we use a shorter time period (1998-2009), as the number of observations in the first years is very low (see Figure 2 Panel C) and Fama and 
MacBeth (1973) regressions assign equal weight to every year in the second stage. Our results for REITs indicate that the size of REIT holdings is positively related to performance when we control for investment approach (Model 3). There is no significant relation between investment costs or approach and net benchmark-adjusted returns in REITs.

We find significantly positive economies of scale for direct real estate. A one unit increase in the log of direct real estate assets improves the performance by 43 basis points (Model 1). Higher investment costs in direct real estate are disproportionally negatively related to net benchmark-adjusted returns. Greater allocation to external managers and fund-of-funds also results in lower returns from direct real estate. Investing in direct real estate only via external managers instead of internal selection of properties results in a 122 basis point annual decrease in the returns. A complete switch to fund-of-funds from internal management reduces the returns by 263 basis points.

In Table 9 Panel $\mathrm{C}$ we analyze the relation between performance and characteristics per investment approach. Mandate size and costs refer to internal, external and fund-of-funds ${ }^{19}$ investments, respectively. Our results show that larger funds have better returns within both internal and external investments. For externally managed portfolios, a one unit increase in the log of assets owned improves the annual net benchmark-adjusted returns by 35 basis points (Model 1). The scale effect is even bigger for internal management, where a one unit increase in the log of assets managed increases the returns by 43 basis points (Model 1). Investment costs are negatively related to external management returns. A 100 basis point increase in the costs reduces returns by 133 basis points per year (Model 2).

In the previous section we showed that the last two years of down-market had a strong influence on performance. As a robustness check, in Appendix Table A.1 we examine whether the exclusion of the 2008-2009 period has an influence on the relation between pension fund performance and characteristics. Our findings that size is positively related to performance, while external management and investing in fund-of-funds have negative effect on returns, remain unchanged. Moreover, the economic effects of log real estate asset become even stronger.

Summarizing, we show that funds investing internally perform better than those opting for external management. Internal management can potentially reduce agency conflicts from multiple layers and bears lower investment costs. Moreover, larger funds apparently have better skills, which enables them to select better properties when investing internally, and to select better money managers when investing externally. When investing externally, larger funds are likely to get preferential treatment, have greater monitoring capacity and may have access to better investment opportunities at lower cost. Finally, investing through fund-of-funds results in substantial underperformance of more than 200 basis points per year as compared to other investment approaches, due to multiple layers of fees and greater agency conflicts.

\footnotetext{
${ }^{19}$ For fund-of-funds we focus on a shorter time period (2007-2009) because the number of observations in the earlier years is very low (see Figure 4 Panel B).
} 


\subsection{Persistence}

We find that pension funds generally meet, but do not exceed the performance of their benchmarks, and that performance is positively related to the size of real estate holdings, and to the implementation of internal management. In this section we examine whether there is persistence in pension fund real estate performance, splitting pension funds into five quintiles based on their net benchmark-adjusted returns. Table 10 presents the transition matrixes, i.e., the probabilities that a fund ranked in one of the five quintiles in year $t$ ends up in one of quintiles in year $(t+1)$. We also investigate the difference in returns in year $(t+1)$ between funds ranked in the lowest and highest quintile in year $t$. Under the null hypothesis of no persistence, the value of the difference in returns in year $(t+1)$ should be centered on zero, which would mean that past performance is no predictor of future performance. Carpenter and Lynch (1999) show that the t-test for the difference between top and bottom portfolios ranked by past performance is best specified under the null hypothesis of no persistence, and it is the most powerful against the alternatives considered. ${ }^{20}$

In Panel A of Table 10 we document strong performance persistence in pension fund real estate performance. Funds are more likely to end up in a better performing quintile next year if they also do so this year, and they are more likely to perform worse in the ranking next year if they performed relatively poorly this year. The overall persistence is mainly due to the persistence in direct real estate performance, as Panel B shows. The last columns of the table provide the year $(t+1)$ average net benchmark-adjusted return for the funds belonging to the lowest and highest ranked quintiles in year $t$, and the t-statistic for the difference between the two returns. Panel B shows that the year $(t+1)$ returns for the bottom quintile is -3.26 percent, whereas the top quintile has an average return of 1.56 percent. Hence, the difference in performance in the following year between the highest and lowest quintile is substantial, equaling 4.82 percentage points, and it is statistically significant, with a t-statistic of 6.23 .

The persistence in performance may potentially be explained by the fact that direct real estate returns are susceptible to appraisal smoothing of property valuations. ${ }^{21}$ However, Geltner and Goetzmann (2000) argue that the NCREIF Property Index, which captures direct real estate investments, is more like an annual index, partially updated each quarter. Hence, the use of annual returns in this paper helps minimize the problems associated with "stale" appraisals of direct real estate returns. Additionally, we also address the persistence in pension fund performance in direct real estate by using a two-year horizon, when the appraisal smoothing effect has lapsed. Table 10 Panel C shows that 29.82 percent of the funds in the best performing quintile in year $t$ will end up in the same quintile two years

\footnotetext{
${ }^{20}$ Similar methodology has been used by Tonks (2005) to examine the persistence in pension fund returns and Carhart (1997) to examine the performance persistence among mutual funds.

${ }^{21}$ For instance, the NCREIF database has various statistical problems, including smoothing and lagging due to the partial adjustment in the index caused by the stale valuations, and artificial seasonality in the index returns due to the bunching of the reappraisals in the fourth calendar quarter.
} 
later. Funds are also more likely to end up in the worst performing quintile in year $(t+2)$, if they were ranked in that quintile in year $t$. The difference in returns in years $(t+2)$ between the best and worst performing funds ranked in year $t$ is 1.98 percentage points (t-statistic of 2.46).

Our results in Panel D show that there is no persistence in REIT performance. Funds ranked in the highest quintile are most likely to end up in the bottom quintile in the next year. The difference in returns between top and bottom ranked funds in the following year is small and not significant.

These results suggest that certain pension funds are persistently more likely to outperform their direct real estate benchmarks, while that is not the case for REIT investors. This may be explained by the fact that direct real estate markets are illiquid and not very transparent, which may give insiders an edge. The higher transparency due to the stock listing of REITs, on the other hand, makes the REIT market more efficient and outperformance more difficult. This may explain why we observe persistence among direct real estate investments, even on a two-year horizon, but not among REITs investments. Additionally, higher transaction costs and market illiquidity limit the possibility to exploit persistence in direct real estate returns.

Prior research on performance persistence in real estate has arrived to similar conclusions. Among mutual funds that invest only in the REIT sector, Kallberg, Liu, and Trzcinka (2000) document little evidence of persistence. On the other hand, among fund managers of real estate opportunity funds, Hahn, Geltner, and Gerardo-Lietz (2005) find some evidence of persistence. The performance of a manager's earlier fund may account for more than 20 percent of a next fund's ranking relative to its vintage year peers. However, even in direct real estate, on a medium and long-term horizon, Bond and Mitchell (2010) find little evidence of performance persistence in fund returns.

Similar to our finding of persistence in direct real estate performance, persistence has been documented also among private equity funds and hedge funds, other illiquid alternative asset classes. Kaplan and Schoar (2005) document substantial persistence in leverage buyout (LBO) and venture capital (VC) fund performance. General partners (GPs) whose private equity funds outperform the industry in one fund are likely to outperform the industry in the next and vice versa. Fung, Hsieh, Naik, and Ramadorai (2008) find that better performing hedge funds that generate positive alpha are less likely to be liquidated, and have a higher propensity to persistently deliver alpha.

\section{Conclusion}

This is the first paper to investigate how tax-exempt money managers across the globe invest in the most important alternative asset class - real estate. As in private equity, pension funds face a palette of choices to deploy capital in the illiquid property market, but not much is known about the approach, costs and performance of their real estate allocations. We use the CEM database, which covers 884 U.S., Canadian, European and Australian/New Zealand pension funds for the period 1990-2009. These 
pension funds had a combined assets under management of $\$ 4.6$ trillion in 2009 .

We document that the costs and performance of pension funds' real estate investments are driven by three main variables: size, the choice to invest internally or externally, and region. We find strong scale advantages in pension fund real estate investments: large pension funds not only have lower costs, but also have better net benchmark-adjusted performance. This is partly due to the fact that larger funds are more likely to opt for internal management, rather than selecting external money managers. Internal management is associated with substantially lower costs than external managers, and also with better performance, even before subtracting costs. Moreover, even when large pension funds choose an external investment approach, they do that with more success than smaller pension funds in our sample.

Overall, the behavior of small and large pension funds suggests that there may be differences between the two groups, with relatively less sophisticated investors among smaller funds, and more sophisticated investors, with an ability to detect profitable real estate investments, among larger funds. Lerner, Schoar, and Wongsunwai (2007) document that agency conflicts and information gaps associated with assessing private equity funds' portfolios lead to dramatic disparities in the performance of venture capital investments across different classes of institutional investors. We document that such information gaps and agency problems can lead to performance differences also within one class of institutional investors, pension funds, and they are driven mainly by fund size. Small and large pension funds invest very differently in real estate. Larger funds can assert more negotiating power in real estate investments, which leads to access to better investment opportunities at lower costs. Larger funds can also commit more resources to monitor real estate investments or even establish internal divisions, which improves their performance.

Surprisingly, larger funds are also more likely to invest in REITs, whereas smaller funds allocate more assets to fund-of-funds in direct real estate. Investing through fund-of-funds results in substantial underperformance compared to other investment approaches. This is at least partly due to multiple layers of fees, but neither do the fund-of-funds seem to have good skills in selecting investment managers, since their gross benchmark-adjusted returns are significantly negative. Hence, especially smaller pension funds do not seem to recognize that REITs provide exposure to property returns comparable to external managers that invest in direct real estate, and much better than fund-of-funds managers, but with much lower investment costs.

Fund-of-funds in direct real estate perform worse than REIT mutual funds and funds investing in hedge funds. The literature on the performance of REIT mutual funds shows that this industry generates an average alpha that is either zero or significantly positive. For instance, using fund holdings and trades of REITs, Cici, Corgel, and Gibson (2011) find that REIT fund managers generate significant positive alpha with their securities selection ability. Similarly, Kallberg, Liu, and Trzcinka (2000) find that REIT mutual funds during the 1986-1998 period obtained significant abnormal net returns. On 
the other hand, Chiang, Kozhevnikov, Lee, and Wisen (2008) show that REIT mutual funds perform no better than a strategy of randomly investing in REITs, and Hartzell, Mühlhofer, and Titman (2010) find that a value-weighted portfolio of all REIT mutual funds delivers alpha close to zero and fails to outperform any alternative benchmarks net of fees. Funds investing in hedge funds deliver small alphas, albeit sporadically, (Fung, Hsieh, Naik, and Ramadorai (2008)), but there is no significant underperformance among hedge funds-of-funds either. So even against these benchmarks, fund-of-funds in direct real estate perform very poorly, and it seems surprising that small pension funds increasingly use their services. On the other hand, this behavior is consistent with the Lakonishok, Shleifer, and Vishny (1992) model of pension fund portfolio management, namely, that despite higher costs and lower returns, pension funds will maintain a preference for external management and fund-of-funds, as a way to shift responsibility for potentially poor performance, and even to shift the responsibility for poor selection of managers to the fund-of-funds.

Another notable finding in this paper is that U.S. pension funds perform relatively poor as compared to international counter-parts. They face much higher costs than their peers in Canada, Europe and Australia/New Zealand, and their performance is worse. This is partly explained by the fact that U.S. funds are less likely to opt for internal management, but further analysis shows that tax-exempt money managers in the U.S., like private investors, seem to have engaged in "irrational exuberance" during the most recent real estate bubble. Excessive use of leverage may be responsible for the initial outperformance of the benchmarks by the U.S. pension funds, as well as for the subsequent collapse in their real estate returns.

Of course, this paper only discusses the average performance of pension funds in real estate. Some individual pension funds genuinely perform well, and some execute better monitoring and governance of their investments than others. The paper has some implications for institutional investors investing in real estate. Pension funds should consider the full range of potential investment approaches and avoid extended investment chains. Particularly, smaller funds should consider using more REITs and should re-evaluate their extensive use of fund-of-funds to gain exposure to direct real estate. Smaller pension funds can also implement more passive strategies in REIT investments in order to remain cost-competitive with larger funds. 


\section{References}

Andonov, A., R. Bauer, And M. Cremers (2011): "Can large pension funds beat the market? Asset allocation, market timing, security selection and the limits of liquidity," Working Paper, Maastricht and Yale University.

Bauer, R., M. Cremers, and R. Frehen (2010): "Pension fund performance and costs: Small is beautiful," Working Paper, Maastricht and Yale University.

Bauer, R., P. Eichholtz, And N. KoK (2010): "Corporate governance and performance: The REIT effect," Real Estate Economics, 38(1), 1-29.

Bond, S., And P. Mitchell (2010): "Alpha and persistence in real estate fund performance," The Journal of Real Estate Finance and Economics, 41(1), 53-79.

Brounen, D., P. Eichholtz, And D. Ling (2007): "Trading intensity and real estate performance," Journal of Real Estate Finance and Economics, 35(1), 449-474.

Brounen, D., M. Prado, and M. Verbeek (2010): "Real estate in an ALM framework: The case of fair value accounting," Real Estate Economics, 38(4), 775-804.

Carhart, M. (1997): "On persistence in mutual fund performance," The Journal of Finance, 52(1), $57-82$.

Carpenter, J., and A. Lynch (1999): "Survivorship bias and attrition effects in measures of performance persistence," Journal of Financial Economics, 54(3), 337-374.

Chinang, K., K. Kozhevnikov, M.-L. Lee, and C. Wisen (2008): "Further evidence on the performance of real estate funds: The case of real estate mutual funds," Real Estate Economics, $36(1), 47-62$.

Chun, G., B. Ciochetti, and J. Shilling (2000): "Pension-plan real estate investment in an asset-liability framework," Real Estate Economics, 28(3), 467-491.

Cici, G., J. Corgel, and S. Gibson (2011): "Can fund managers select outperforming REITs? Examining fund holdings and trades," Real Estate Economics, 39(3), 455-486.

Ciochetti, B., T. Craft, and J. Shilling (2002): "Institutional investors' preferences for REIT stocks," Real Estate Economics, 30(4), 567-593.

Dyck, A., And L. Pomorski (2011): "Is bigger better? Size and performance in pension plan management," Working Paper, University of Toronto.

EnNis, R., AND P. BuRIK (1991): "Pension fund real estate investment under a simple equilibrium pricing model," Financial Analysts Journal, 47(3), 20-30.

FAma, E., AND J. MacBeth (1973): "Risk, return, and equilibrium: Empirical tests," The Journal of Political Economy, 81(3), 607-636.

Fisher, J., And W. Goetzmann (2005): "Performance of real estate portfolios," The Journal of Portfolio Management, 31(5), 32-45.

Fisher, J., D. Ling, and A. Naranjo (2009): "Institutional capital flows and return dynamics in private commercial real estate markets," Real Estate Economics, 37(1), 85-116.

French, K. (2008): "Presidential address: The cost of active investing," The Journal of Finance, 63(4), 1537-1573.

Friedman, H. (1971): "Real estate investment and portfolio theory," Journal of Financial and Quantitative Analysis, 6(2), 861-874. 
Fung, W., D. Hsieh, N. Naik, and T. Ramadorai (2008): "Hedge funds: Performance, risk, and capital formation," The Journal of Finance, 63(4), 1777-1803.

Geltner, D., And W. Goetzmann (2000): "Two decades of commercial property returns: A repeated-measures regression-based version of the NCREIF index," The Journal of Real Estate Finance and Economics, 21(1), 5-21.

Hahn, T., D. Geltner, and N. Gerardo-Lietz (2005): "Real estate opportunity funds," The Journal of Portfolio Management, 31(5), 143-153.

Hartzell, J., T. Mühlhofer, and S. Titman (2010): "Alternative benchmarks for evaluating mutual fund performance," Real Estate Economics, 38(1), 121-154.

Hochberg, Y., And T. Mühlhofer (2011): "Market timing and investment selection: Evidence from real estate investors," Working Paper, Northwestern and Indiana University.

Hudson-Wilson, S., J. Gordon, F. Fabozzi, M. Anson, and S. Giliberto (2005): "Why real estate?," The Journal of Portfolio Management, 31(5), 12-21.

Kallberg, J., C. Liu, and D. Greig (1996): "The role of real estate in the portfolio allocation process," Real Estate Economics, 24(3), 359-377.

Kallberg, J., C. Liu, and C. Trzcinka (2000): "The value added from investment managers: An examination of funds of REITs," Journal of Financial and Quantitative Analysis, 35(3), 387-408.

Kaplan, S., And A. SchoAR (2005): "Private equity performance: Returns, persistence, and capital flows," The Journal of Finance, 60(4), 1791-1823.

Lakonishok, J., A. Shleifer, and R. Vishny (1992): "The structure and performance of the money management industry," Brookings Papers on Economic Activity. Microeconomics, pp. 339-391.

Lerner, J., A. Schoar, and W. Wongsunwai (2007): "Smart institutions, foolish choices: The limited partner performance puzzle," The Journal of Finance, 62(2), 731-764.

Ling, D., And A. NARAnJo (2006): "Dedicated REIT mutual fund flows and REIT performance," The Journal of Real Estate Finance and Economics, 32(4), 409-433.

Pagliari, J. J., K. Scherer, and R. Monopoli (2005): "Public versus private real estate equities: A more refined, long-term comparison," Real Estate Economics, 33(1), 147-187.

Phalippou, L. (2009): "Beware of venturing into private equity," Journal of Economic Perspectives, $23(1), 147-66$.

Phalippou, L., and O. Gottschalg (2009): "The performance of private equity funds," Review of Financial Studies, 22(4), 1747-1776.

Swamy, P. (1970): "Efficient inference in a random coefficient regression model," Econometrica, 38(2), $311-323$.

Tonks, I. (2005): "Performance persistence of pension-fund managers," Journal of Business, 78(5), $1917-1942$.

WebB, J. (1990): "On the exclusion of real estate from the market portfolio," The Journal of Portfolio Management, 17(1), 78-84.

Webb, J., And J. Rubens (1987): "How much in real estate? A surprising answer," The Journal of Portfolio Management, 13(3), 10-14. 


\section{Table 1: The CEM database}

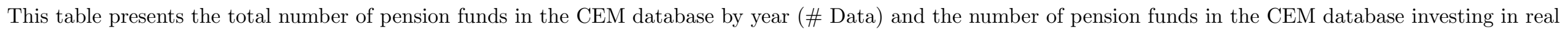
estate (\# RE). The "Size" column shows the average total assets under management (in billion US\$) of the pension funds in the database.

\begin{tabular}{|c|c|c|c|c|c|c|c|c|c|c|c|c|c|c|c|}
\hline \multirow[t]{2}{*}{ Year } & \multicolumn{3}{|c|}{ All funds } & \multicolumn{3}{|c|}{ U.S. } & \multicolumn{3}{|c|}{ Canada } & \multicolumn{3}{|c|}{ Europe } & \multicolumn{3}{|c|}{ Aus/Nzd } \\
\hline & \# Data & \# RE & Size & \# Data & \# RE & Size & \# Data & \# RE & Size & \# Data & \# RE & Size & \# Data & \# RE & Size \\
\hline 1990 & 88 & 70 & 4.93 & 35 & 30 & 9.46 & 53 & 40 & 1.94 & & & & & & \\
\hline 1991 & 124 & 101 & 4.55 & 63 & 52 & 7.28 & 61 & 49 & 1.72 & & & & & & \\
\hline 1992 & 164 & 130 & 4.59 & 83 & 68 & 7.45 & 81 & 62 & 1.66 & & & & & & \\
\hline 1993 & 220 & 161 & 4.27 & 134 & 100 & 5.92 & 86 & 61 & 1.71 & & & & & & \\
\hline 1994 & 269 & 202 & 3.78 & 168 & 128 & 4.85 & 98 & 71 & 1.58 & 3 & 3 & 15.42 & & & \\
\hline 1995 & 298 & 224 & 4.42 & 192 & 152 & 5.64 & 102 & 68 & 1.75 & 4 & 4 & 13.96 & & & \\
\hline 1997 & 273 & 202 & 5.96 & 168 & 131 & 7.73 & 97 & 63 & 2.58 & 8 & 8 & 9.77 & & & \\
\hline 1998 & 286 & 202 & 6.78 & 174 & 133 & 9.11 & 104 & 62 & 2.51 & 8 & 7 & 11.60 & & & \\
\hline 1999 & 306 & 208 & 8.15 & 182 & 137 & 10.41 & 110 & 59 & 2.55 & 14 & 12 & 22.80 & & & \\
\hline 2000 & 285 & 202 & 9.06 & 164 & 125 & 12.02 & 104 & 62 & 2.86 & 15 & 13 & 20.59 & 2 & 2 & 2.05 \\
\hline 2001 & 294 & 200 & 8.56 & 176 & 125 & 10.56 & 99 & 58 & 3.00 & 17 & 15 & 20.98 & 2 & 2 & 2.13 \\
\hline 2002 & 274 & 184 & 8.37 & 156 & 112 & 10.80 & 98 & 55 & 2.64 & 16 & 14 & 21.29 & 4 & 3 & 2.19 \\
\hline 2003 & 279 & 190 & 9.21 & 158 & 118 & 11.01 & 96 & 53 & 3.07 & 20 & 15 & 25.46 & 5 & 4 & 5.22 \\
\hline 2004 & 288 & 210 & 10.72 & 167 & 132 & 12.18 & 96 & 57 & 4.01 & 18 & 15 & 34.76 & 7 & 6 & 6.23 \\
\hline 2006 & 291 & 216 & 14.54 & 147 & 121 & 15.80 & 102 & 58 & 6.99 & 29 & 25 & 37.09 & 13 & 12 & 9.19 \\
\hline 2007 & 354 & 258 & 14.16 & 217 & 167 & 12.72 & 98 & 56 & 8.26 & 28 & 25 & 47.76 & 11 & 10 & 9.58 \\
\hline 2008 & 368 & 280 & 13.32 & 211 & 159 & 12.30 & 90 & 61 & 8.92 & 58 & 52 & 24.41 & 9 & 8 & 9.87 \\
\hline 2009 & 351 & 260 & 13.28 & 203 & 153 & 12.22 & 92 & 55 & 7.44 & 50 & 47 & 27.89 & 6 & 5 & 16.98 \\
\hline Total & 884 & 668 & & 536 & 409 & & 244 & 163 & & 86 & 79 & & 18 & 17 & \\
\hline
\end{tabular}




\section{Table 2: Descriptive statistics: real estate holdings}

This table provides descriptive statistics of pension funds' investments in real estate. We present the time series averages of cross-sectional statistics for the 1990-2009 time period. We show the following statistics: $25^{\text {th }}$ percentile, median, mean, $75^{\text {th }}$ percentile and standard deviation (StDev). Columns \# Funds and \# Obs present the number of funds investing in real estate or in one of the subcategories and the number of observations. Panel A presents the descriptive statistics of real estate assets as a percentage of total pension fund assets, considering only pension funds that invest in real estate. Panels B, C and D display the summary statistics of real estate holdings in million US\$. In Panel B the real estate assets descriptive statistics are presented separately for U.S., Canadian, European and Australian/New Zealand funds. In Panel C we split the real estate investments into the following subcategories: real estate investment trusts (REITs), direct real estate and other real assets. Panel D presents the real estate holdings summary statistics by investment approach. For internal and external statistics we use the entire period 1990-2009. Fund-of-funds exist in the data since 1995 and we present the time series averages of cross-sectional statistics for the 1995-2009 period. As the number of fund-of-funds observations is low before 2007, we report only the median, mean and standard deviation values.

\begin{tabular}{|c|c|c|c|c|c|c|c|}
\hline & $25^{\text {th }}$ & Median & Mean & $75^{\text {th }}$ & StDev & \# Funds & \# Obs \\
\hline \multicolumn{8}{|c|}{ Panel A: Real estate assets as a percentage of total fund size } \\
\hline All funds & $2.67 \%$ & $4.83 \%$ & $5.36 \%$ & $7.51 \%$ & $3.71 \%$ & 668 & 3928 \\
\hline U.S. & $2.87 \%$ & $4.91 \%$ & $5.18 \%$ & $7.27 \%$ & $3.25 \%$ & 409 & 2408 \\
\hline Canada & $2.01 \%$ & $4.15 \%$ & $4.68 \%$ & $6.58 \%$ & $3.36 \%$ & 163 & 1178 \\
\hline Europe & $6.78 \%$ & $11.00 \%$ & $10.85 \%$ & $13.46 \%$ & $5.01 \%$ & 79 & 281 \\
\hline Aus/Nzd & $7.26 \%$ & $9.55 \%$ & $9.67 \%$ & $11.56 \%$ & $3.80 \%$ & 17 & 61 \\
\hline \multicolumn{8}{|c|}{ Panel B: Real estate holdings in million US\$ } \\
\hline All funds & 33 & 116 & 650 & 415 & 1,578 & 668 & 3928 \\
\hline U.S. & 48 & 147 & 647 & 483 & 1,417 & 409 & 2408 \\
\hline Canada & 15 & 47 & 399 & 144 & 1,072 & 163 & 1178 \\
\hline Europe & 468 & 1,049 & 2,311 & 2,458 & 3,589 & 79 & 281 \\
\hline Aus/Nzd & 267 & 451 & 668 & 912 & 626 & 17 & 61 \\
\hline \multicolumn{8}{|c|}{ Panel C: Real estate holdings by subcategory in million US\$ } \\
\hline REITs & 35 & 104 & 407 & 290 & 1,290 & 220 & 966 \\
\hline Direct real estate & 29 & 107 & 549 & 361 & 1,235 & 635 & 3616 \\
\hline Other real assets & 11 & 73 & 183 & 207 & 332 & 88 & 274 \\
\hline \multicolumn{8}{|c|}{ Panel D: Real estate holdings by investment approach in million US\$ } \\
\hline Internal & 55 & 230 & 899 & 898 & 1,690 & 160 & 914 \\
\hline External & 29 & 92 & 517 & 342 & 1,242 & 611 & 3324 \\
\hline Fund-of-funds & - & 83 & 96 & - & 50 & 32 & 94 \\
\hline
\end{tabular}




\section{Table 3: Descriptive statistics: investment approach}

This table shows the real estate investment approach of pension funds. For every variable we present the time series averages of cross-sectional means. Columns \%Ext and \%Int present the percentage of assets managed externally and internally in the period 1990-2009. \% FoF shows the percentage of assets invested in fund-of-funds during the 20 years period. For REITs we also display the percentage of assets managed actively (\%Act) and passively (\% Pas). For direct real estate we add the percentage of assets invested in limited partnerships (\%LP), which is combined with \%Ext for All real estate, and in Panel B. Panel B shows the investment approach separately for U.S., Canadian, European and Australian/New Zealand funds.

\begin{tabular}{|c|c|c|c|c|c|c|}
\hline & $\%$ Ext & $\%$ Int & $\% \mathrm{FoF}$ & $\% \mathrm{LP}$ & $\%$ Act & $\%$ Pas \\
\hline \multicolumn{7}{|c|}{ Panel A: Real estate investment approach by subcategory } \\
\hline All real estate & $79.63 \%$ & $18.94 \%$ & $1.43 \%$ & - & - & - \\
\hline REITs & $54.66 \%$ & $45.34 \%$ & - & - & $94.05 \%$ & $5.95 \%$ \\
\hline Direct real estate & $78.41 \%$ & $16.81 \%$ & $1.74 \%$ & $3.04 \%$ & - & - \\
\hline Other real assets & $64.33 \%$ & $35.67 \%$ & - & - & - & - \\
\hline \multicolumn{7}{|c|}{ Panel B: Real estate investment approach by region } \\
\hline U.S. & $90.40 \%$ & $7.62 \%$ & $1.97 \%$ & - & - & - \\
\hline Canada & $64.25 \%$ & $35.62 \%$ & $0.13 \%$ & - & - & - \\
\hline Europe & $47.11 \%$ & $51.48 \%$ & $1.41 \%$ & - & - & - \\
\hline Aus/Nzd & $84.41 \%$ & $14.85 \%$ & $0.74 \%$ & - & - & - \\
\hline
\end{tabular}




\section{Table 4: Investing in real estate and pension fund characteristics}

In Panel A we present the marginal effects (elasticities) at the means of the independent variables. The marginal effects for the dummy variables are estimated for discrete changes from 0 to 1 . We also include year dummies and cluster the standard errors by pension fund, allowing for intragroup correlation. Columns (1) and (2) in Panel A provide the results of logit regressions explaining whether a pension fund invests in real estate or not. In columns (3) and (4), and (5) and (6) we address the relation between pension fund characteristics and decision to invest in REITs or direct real estate, taking into account only funds which invest in real estate. As independent variables we include Fund size - logarithm of total pension fund assets, Alternatives - strategic asset allocation to other alternative asset classes, Public and Other - dummy variables capturing pension fund type (the base result refers to Corporate funds), Canada, Europe and Aus/Nzd - regional dummy variables (the base result refers to U.S. funds). In Panel B we split the funds into five quintiles every year based on their total assets under management. Column (1) presents the time series averages of cross-sectional fund size means per quintile. Column (2) shows the percentage of funds not investing in real estate. Column (3) shows the percentage of funds investing in REITs, but not in direct real estate. Column (4) displays the percentage of funds investing in direct real estate, but not in REITs. Column (5) presents the percentage of funds investing in both REITs and direct real estate. Finally, column (6) shows the percentage of funds investing in other real assets, but not in REITs and direct real estate. We report standard errors in brackets and significance levels with *, ** and ***, which correspond to $0.10,0.05$ and 0.01 , respectively.

\begin{tabular}{|c|c|c|c|c|c|c|}
\hline & \multicolumn{2}{|c|}{ Does a PF invest in real estate? } & \multicolumn{4}{|c|}{ If a PF invests, does it invest in REITs or Direct RE? } \\
\hline & $\begin{array}{c}\text { Real estate } \\
(1)\end{array}$ & $\begin{array}{c}\text { Real estate } \\
(2)\end{array}$ & $\begin{array}{c}\text { REITs } \\
(3)\end{array}$ & $\begin{array}{l}\text { REITs } \\
(4)\end{array}$ & $\begin{array}{c}\text { Direct RE } \\
(5)\end{array}$ & $\begin{array}{c}\text { Direct RE } \\
(6)\end{array}$ \\
\hline \multirow[t]{2}{*}{ Fund size } & $0.082^{* * *}$ & $0.078^{* * *}$ & $0.058^{* * *}$ & $0.042^{* * *}$ & -0.000 & 0.006 \\
\hline & {$[0.012]$} & {$[0.012]$} & {$[0.010]$} & {$[0.010]$} & {$[0.007]$} & [0.008] \\
\hline \multirow[t]{2}{*}{ Alternatives } & $1.408^{* * *}$ & $1.400^{* * *}$ & -0.208 & -0.260 & $0.283^{* *}$ & $0.258^{*}$ \\
\hline & {$[0.348]$} & {$[0.349]$} & {$[0.164]$} & {$[0.168]$} & {$[0.139]$} & {$[0.149]$} \\
\hline \multirow[t]{2}{*}{ Public } & & 0.023 & & 0.029 & & -0.027 \\
\hline & & {$[0.033]$} & & {$[0.031]$} & & {$[0.025]$} \\
\hline \multirow[t]{2}{*}{ Other } & & 0.064 & & 0.010 & & 0.024 \\
\hline & & {$[0.044]$} & & {$[0.046]$} & & {$[0.018]$} \\
\hline \multirow[t]{2}{*}{ Canada } & & -0.005 & & $-0.116^{* * *}$ & & 0.012 \\
\hline & & [0.034] & & {$[0.029]$} & & {$[0.025]$} \\
\hline \multirow[t]{2}{*}{ Europe } & & 0.092 & & $0.185^{* * *}$ & & -0.052 \\
\hline & & {$[0.066]$} & & {$[0.085]$} & & {$[0.041]$} \\
\hline \multirow[t]{2}{*}{ Aus/Nzd } & & 0.098 & & 0.103 & & 0.021 \\
\hline & & [0.103] & & [0.098] & & {$[0.025]$} \\
\hline Year dummies & Yes & Yes & Yes & Yes & Yes & Yes \\
\hline Observations & 5406 & 5406 & 3928 & 3928 & 3928 & 3928 \\
\hline Fund clusters & 884 & 884 & 668 & 668 & 668 & 668 \\
\hline Pseudo $\mathrm{R}^{2}$ & 0.109 & 0.115 & 0.202 & 0.245 & 0.054 & 0.067 \\
\hline
\end{tabular}

Panel B: Sorting: whether and how pension funds invest in real estate per size quintile

\begin{tabular}{lcccccc}
\hline $\begin{array}{l}\text { Fund size } \\
\text { quintiles }\end{array}$ & $\begin{array}{c}\text { Average size } \\
\text { in mil. US\$ } \\
(1)\end{array}$ & $\begin{array}{c}\text { No real } \\
\text { estate } \\
\text { 1 Smallest }\end{array}$ & $\begin{array}{c}\text { REITs, no } \\
\text { Direct RE }\end{array}$ & $\begin{array}{c}\text { Direct RE, } \\
\text { no REITs } \\
(3)\end{array}$ & $\begin{array}{c}\text { REITs and } \\
\text { Direct RE } \\
(5)\end{array}$ & $\begin{array}{c}\text { Only other } \\
\text { real assets } \\
(6)\end{array}$ \\
\hline 2 & 336 & $51 \%$ & $2 \%$ & $42 \%$ & $3 \%$ & $2 \%$ \\
3 & 2075 & $30 \%$ & $5 \%$ & $57 \%$ & $7 \%$ & $2 \%$ \\
4 & 5236 & $23 \%$ & $4 \%$ & $57 \%$ & $13 \%$ & $3 \%$ \\
5 Largest & 32973 & $9 \%$ & $2 \%$ & $57 \%$ & $17 \%$ & $1 \%$ \\
\hline
\end{tabular}




\section{Table 5: Investment approach and pension fund characteristics}

Panel A provides the results of logit regressions explaining whether a pension fund invests in real estate internally $((1)$ and (2)), externally $((3)$ and (4)) or via fund-of-funds ((5) and (6)). We present the marginal effects (elasticities) at the means of the independent variables. The marginal effects for the dummy variables are estimated for discrete changes from 0 to 1 . We also include year dummies and cluster the standard errors by pension fund, allowing for intragroup correlation. As independent variables we include Fund size - log of total pension fund assets, Alternatives - strategic allocation to other alternative asset classes, \%REITs - allocation to real estate investment trusts (REITs) as a percentage of all real estate assets, Public and Other - dummy variables capturing pension fund type (the base result refers to Corporate funds), Canada, Europe and Aus/Nzd - regional dummy variables (the base result refers to U.S. funds). In Panel B we split the funds into five quintiles every year based on their total assets. Column (1) shows the percentage of funds investing only internally in real estate. Column (2) presents the percentage of funds investing only externally. Column (3) displays the percentage of funds investing only via fund-of-funds. Column (4) presents the percentage of funds investing internally and externally, but not via fund of funds. Column (5) shows the funds investing internally and via fund-of-funds, but not externally. Column (6) displays the percentage of funds investing externally and via fund-of-funds, but not internally. Finally, Column (7) displays the percentage of funds investing in real assets using all three investment approaches at the same time. We report standard errors in brackets and significance levels with $*, * *$ and $* * *$, which correspond to $0.10,0.05$ and 0.01 , respectively.

\begin{tabular}{|c|c|c|c|c|c|c|}
\hline & $\begin{array}{l}\text { Internal } \\
(1)\end{array}$ & $\begin{array}{c}\text { Internal } \\
(2)\end{array}$ & $\begin{array}{c}\text { External } \\
(3)\end{array}$ & $\begin{array}{c}\text { External } \\
(4)\end{array}$ & $\begin{array}{l}\text { FoF } \\
(5)\end{array}$ & $\begin{array}{l}\text { FoF } \\
(6)\end{array}$ \\
\hline \multirow[t]{2}{*}{ Fund size } & $0.075^{* * *}$ & $0.100 * * *$ & -0.015 & $-0.026^{* *}$ & $-0.005^{*}$ & $-0.005^{* *}$ \\
\hline & {$[0.013]$} & {$[0.016]$} & {$[0.010]$} & {$[0.010]$} & {$[0.003]$} & {$[0.002]$} \\
\hline \multirow[t]{2}{*}{ Alternatives } & $-1.200 * * *$ & -0.397 & $1.064 * * *$ & $0.507 * *$ & 0.033 & 0.015 \\
\hline & [0.309] & {$[0.279]$} & {$[0.280]$} & {$[0.215]$} & {$[0.024]$} & {$[0.015]$} \\
\hline \multirow[t]{2}{*}{$\%$ REITs } & $0.138 * *$ & $0.192 * * *$ & $-0.104^{* *}$ & $-0.123^{* * *}$ & -0.016 & $-0.016^{*}$ \\
\hline & {$[0.055]$} & {$[0.050]$} & {$[0.046]$} & {$[0.033]$} & {$[0.016]$} & {$[0.010]$} \\
\hline \multirow[t]{2}{*}{ Public } & & -0.015 & & -0.015 & & 0.014 \\
\hline & & {$[0.040]$} & & {$[0.036]$} & & {$[0.012]$} \\
\hline \multirow{2}{*}{ Other } & & 0.021 & & -0.010 & & -0.005 \\
\hline & & {$[0.050]$} & & {$[0.034]$} & & {$[0.004]$} \\
\hline \multirow[t]{2}{*}{ Canada } & & $0.467 * * *$ & & $-0.284^{* * *}$ & & $-0.018^{* *}$ \\
\hline & & {$[0.062]$} & & {$[0.050]$} & & {$[0.008]$} \\
\hline \multirow[t]{2}{*}{ Europe } & & $0.409 * * *$ & & $-0.232 * * *$ & & 0.021 \\
\hline & & {$[0.101]$} & & {$[0.087]$} & & {$[0.017]$} \\
\hline \multirow{2}{*}{ Aus/Nzd } & & 0.180 & & 0.018 & & 0.027 \\
\hline & & {$[0.137]$} & & {$[0.071]$} & & {$[0.028]$} \\
\hline Year dummies & Yes & Yes & Yes & Yes & Yes & Yes \\
\hline Observations & 3928 & 3928 & 3928 & 3928 & 3928 & 3928 \\
\hline Fund clusters & 668 & 668 & 668 & 668 & 668 & 668 \\
\hline Pseudo $\mathrm{R}^{2}$ & 0.093 & 0.253 & 0.042 & 0.160 & 0.109 & 0.215 \\
\hline
\end{tabular}

Panel B: Sorting: how pension funds invest in real estate per size quintile

\begin{tabular}{|c|c|c|c|c|c|c|c|}
\hline $\begin{array}{l}\text { Fund size } \\
\text { quintiles }\end{array}$ & $\begin{array}{l}\text { Only Int } \\
(1)\end{array}$ & $\begin{array}{c}\text { Only Ext } \\
(2)\end{array}$ & $\begin{array}{c}\text { Only FoF } \\
(3)\end{array}$ & $\begin{array}{c}\text { Int \& Ext } \\
\text { no FoF } \\
(4)\end{array}$ & $\begin{array}{c}\text { Int \& FoF } \\
\text { no Ext } \\
(5)\end{array}$ & $\begin{array}{c}\text { Ext \& FoF } \\
\text { no Int } \\
(6)\end{array}$ & $\begin{array}{c}\text { Int \& Ext } \\
\text { \& FoF } \\
(7)\end{array}$ \\
\hline 1 Smallest & $13.18 \%$ & $82.67 \%$ & $1.51 \%$ & $2.26 \%$ & $0.00 \%$ & $0.38 \%$ & $0.00 \%$ \\
\hline 2 & $10.10 \%$ & $82.55 \%$ & $3.67 \%$ & $2.49 \%$ & $0.00 \%$ & $0.66 \%$ & $0.52 \%$ \\
\hline 3 & $11.25 \%$ & $80.65 \%$ & $1.81 \%$ & $5.44 \%$ & $0.00 \%$ & $0.85 \%$ & $0.00 \%$ \\
\hline 4 & $13.05 \%$ & $76.29 \%$ & $0.00 \%$ & $8.98 \%$ & $0.00 \%$ & $1.56 \%$ & $0.12 \%$ \\
\hline 5 Largest & $20.97 \%$ & $57.04 \%$ & $0.00 \%$ & $20.86 \%$ & $0.00 \%$ & $0.92 \%$ & $0.21 \%$ \\
\hline
\end{tabular}


Table 6: Descriptive statistics: real estate investment costs

This table provides the descriptive statistics on investment costs of pension funds investing in real estate in basis points. The values presented are time series averages of cross-sectional statistics for the 1990-2009 time period (for fund-of-funds 1995-2009). The statistics presented are median, mean and standard deviation (StDev). In Panel A the cost statistics are presented for all funds together, as well as separately for U.S., Canadian, European and Australian/New Zealand funds. In Panel B we split the real estate investment costs into the following subcategories: REITs, direct real estate and other real assets. We also split the REITs investment to two investment approaches: internal and external. For direct real estate we have four approaches: internal, external, limited partnerships and fund-of-funds. Investments in other real assets are done in two ways: internally and externally. Panel $\mathrm{C}$ shows the costs summary statistics per investment approach. Costs for all internal mandates are also a weighted average of internal investment costs across all subcategories. Costs for all external mandates are calculated as a weighted average of costs for external mandates in REITs, external mandates in direct real estate, limited partnerships in direct real estate and external mandates in other real assets. Investments in direct real estate via fund-of-funds are the only category from Panel B not incorporated in Panel C, because we analyze the fund-of-funds as a separate investment approach.

\begin{tabular}{|c|c|c|c|c|c|}
\hline & Median & Mean & StDev & \# Funds & \# Obs \\
\hline \multicolumn{6}{|c|}{ Panel A: Costs in basis points by region } \\
\hline All funds & 67.24 & 76.19 & 84.61 & 662 & 3815 \\
\hline U.S. & 83.48 & 91.12 & 90.61 & 407 & 2353 \\
\hline Canada & 44.97 & 55.54 & 51.55 & 161 & 1144 \\
\hline Europe & 30.31 & 37.62 & 33.74 & 77 & 259 \\
\hline Aus/Nzd & 42.9 & 44.82 & 18.79 & 17 & 59 \\
\hline \multicolumn{6}{|c|}{ Panel B: Costs in basis points by subcategory and investment approach } \\
\hline REITs & 32.75 & 41.45 & 57.18 & 213 & 917 \\
\hline - Internal & 8.35 & 12.06 & 14.04 & 50 & 286 \\
\hline - External & 52.61 & 62.75 & 68.37 & 181 & 698 \\
\hline Direct real estate & 72.47 & 82.89 & 100.3 & 635 & 3595 \\
\hline - Internal & 22.81 & 31.40 & 31.63 & 129 & 675 \\
\hline - External & 78.52 & 88.09 & 85.73 & 567 & 2941 \\
\hline - Limited partnership & 122.58 & 143.15 & 131.74 & 53 & 154 \\
\hline - Fund-of-funds & 170.70 & 182.56 & 43.94 & 32 & 94 \\
\hline Other real assets & 29.32 & 56.91 & 102.09 & 76 & 230 \\
\hline - Internal & 30.11 & 30.74 & 37.27 & 11 & 49 \\
\hline - External & 46.11 & 67.24 & 148.69 & 66 & 182 \\
\hline \multicolumn{6}{|c|}{ Panel C: Real estate costs in basis points by investment approach } \\
\hline Internal & 18.51 & 26.24 & 27.88 & 148 & 834 \\
\hline External & 76.35 & 86.08 & 88.63 & 607 & 3245 \\
\hline
\end{tabular}




\section{Table 7: Regression results: real estate investment costs}

Panel A of this table reports the results of pooled panel regressions of the real estate investment costs for all funds and per region. Panel B reports the results of pooled panel regressions of the investment costs for different real estate subcategories. In Panel $\mathrm{C}$ we use the costs by investment approach as dependent variable. As independent variables, we include the log of real estate assets in millions of dollars (Mandate), and the percentage allocations to externally managed (\%Ext) mandates and fund-of-funds (\%FoF). When analyzing the REITs costs, we include the following independent variables: log of REITs investments (Mandate) and the percentage allocations to externally (\%Ext) and actively (\%Act) managed REIT assets. When analyzing Direct RE costs, we include: log of direct real estate investments (Mandate) and the percentage allocations to externally managed (\%Ext) mandates, limited partnerships (\%LP) and fund-of-funds (\%FoF). In Panel C, Mandate refers to the log of assets managed internally, externally or via fund-of-funds, respectively. We use two types of pooled panel regressions: (1) with year and regional dummies; and (2) with year and fund-fixed effects (FE). All regressions use robust standard errors clustered by fund. We report standard errors in brackets and significance levels with $* * *$ and $* * *$, which correspond to $0.10,0.05$ and 0.01 , respectively.

\begin{tabular}{|c|c|c|c|c|c|c|c|c|c|c|c|}
\hline & Cons. & Mandate & $\%$ Ext & $\%$ Act & $\% \mathrm{FoF}$ & $\% \mathrm{LP}$ & U.S. & Canada & Europe & $\mathrm{FE}$ & $\mathrm{R}^{2}$ \\
\hline \multicolumn{12}{|c|}{ Panel A: Costs regressions for all funds and by region } \\
\hline All funds & $\begin{array}{c}49.02^{* * *} \\
{[17.94]}\end{array}$ & $\begin{array}{c}-9.80 * * * \\
{[0.91]}\end{array}$ & $\begin{array}{c}33.12^{* * *} \\
{[4.96]}\end{array}$ & & $\begin{array}{c}100.49^{* * *} \\
{[13.94]}\end{array}$ & & $\begin{array}{c}40.64^{* * *} \\
{[13.23]}\end{array}$ & $\begin{array}{c}4.36 \\
{[13.58]}\end{array}$ & $\begin{array}{c}13.04 \\
{[14.45]}\end{array}$ & No & 0.10 \\
\hline All funds & $\begin{array}{c}185.96 * * * \\
{[65.96]}\end{array}$ & $\begin{array}{c}-32.25^{* *} \\
{[14.24]}\end{array}$ & $\begin{array}{c}21.36^{* *} \\
{[9.31]}\end{array}$ & & $\begin{array}{c}122.03^{* * *} \\
{[41.95]}\end{array}$ & & & & & Yes & 0.25 \\
\hline U.S. & $\begin{array}{c}222.76^{* *} \\
{[97.62]}\end{array}$ & $\begin{array}{c}-41.51^{* *} \\
{[20.91]}\end{array}$ & $\begin{array}{c}30.87 \\
{[21.15]}\end{array}$ & & $\begin{array}{c}151.48^{* * * *} \\
{[52.75]}\end{array}$ & & & & & Yes & 0.20 \\
\hline Europe & $\begin{array}{c}154.03 \\
{[133.85]}\end{array}$ & $\begin{array}{l}-20.04 \\
{[22.10]}\end{array}$ & $\begin{array}{c}15.85^{* *} \\
{[6.76]}\end{array}$ & & $\begin{array}{l}72.79^{* *} \\
{[35.82]}\end{array}$ & & & & & Yes & 0.76 \\
\hline Aus/Nzd & $\begin{array}{l}-10.65 \\
{[27.83]} \\
\end{array}$ & $\begin{array}{c}1.79 \\
{[4.59]}\end{array}$ & $\begin{array}{c}23.75 \\
{[16.53]}\end{array}$ & & $\begin{array}{c}131.28^{* * *} \\
{[35.60]}\end{array}$ & & & & & Yes & 0.83 \\
\hline \multicolumn{12}{|c|}{ Panel B: Costs regressions by real estate subcategory } \\
\hline Direct & $\begin{array}{c}77.48^{* * *} \\
{[26.59]}\end{array}$ & $\begin{array}{c}-12.72^{* * *} \\
{[1.28]}\end{array}$ & $\begin{array}{c}26.50^{* * *} \\
{[7.10]}\end{array}$ & & $\begin{array}{c}85.71^{* * *} \\
{[17.98]}\end{array}$ & $\begin{array}{c}139.67^{* * *} \\
{[14.67]}\end{array}$ & $\begin{array}{l}33.46^{*} \\
{[18.40]}\end{array}$ & $\begin{array}{c}-9.83 \\
{[18.76]}\end{array}$ & $\begin{array}{c}-0.08 \\
{[20.08]}\end{array}$ & No & 0.09 \\
\hline Direct & $\begin{array}{c}164.89^{* * *} \\
{[62.37]}\end{array}$ & $\begin{array}{c}-25.82^{*} \\
{[13.33]}\end{array}$ & $\begin{array}{c}17.76^{* *} \\
{[8.82]}\end{array}$ & & $\begin{array}{c}135.81^{* * *} \\
{[44.68]}\end{array}$ & $\begin{array}{c}111.42^{*} \\
{[62.76]}\end{array}$ & & & & Yes & 0.61 \\
\hline \multicolumn{12}{|c|}{ Panel C: Costs regressions by investment approach } \\
\hline Internal & $\begin{array}{c}35.09 * * * \\
{[10.82]}\end{array}$ & $\begin{array}{c}-3.57^{* * *} \\
{[0.51]}\end{array}$ & & & & & $\begin{array}{c}-1.9 \\
{[8.27]}\end{array}$ & $\begin{array}{c}4.28 \\
{[8.22]}\end{array}$ & $\begin{array}{l}-1.83 \\
{[8.45]}\end{array}$ & No & 0.08 \\
\hline Internal & $\begin{array}{c}58.34^{* * *} \\
{[16.43]}\end{array}$ & $\begin{array}{c}-6.84^{* *} \\
{[3.06]}\end{array}$ & & & & & & & & Yes & 0.65 \\
\hline External & $\begin{array}{c}85.90 * * * \\
{[21.50]}\end{array}$ & $\begin{array}{c}-11.06^{* * *} \\
{[1.10]}\end{array}$ & & & & & $\begin{array}{c}40.90^{* * *} \\
{[14.89]}\end{array}$ & $\begin{array}{c}-0.54 \\
{[15.40]}\end{array}$ & $\begin{array}{c}15.46 \\
{[16.61]}\end{array}$ & No & 0.05 \\
\hline
\end{tabular}




\section{Table 8: Pension fund returns in real estate investments}

This table presents the pension fund returns in real estate in percentages. Panel A presents the time series averages of cross-sectional mean gross returns for the 1990-2009 time period (for fund-of-funds 1995-2009). Standard deviations of the gross returns are in the brackets. In Panel B we deduct the self-declared benchmark returns from the pension fund returns, which corresponds to gross benchmark-adjusted returns. In Panel $\mathrm{C}$ we also deduct the investment costs and look at net benchmark-adjusted returns. In Panels $\mathrm{B}$ and $\mathrm{C}$ we run a random coefficient model only with a constant for every fund that has at least 3 observations. The All assets column presents the constants for the performance in all real estate assets together for all funds and per region. The next columns present the constants for performance in subcategories: REITs, direct real estate and other real assets. The last three columns report the performance of different investment approaches: internal, external and fund-of-funds (FoF). For every regression we report the number of funds / observations, constant and standard error in brackets, and denote significance levels with *, ${ }^{* *}$ and $* * *$, which correspond to $0.10,0.05$ and 0.01 , respectively.

\begin{tabular}{|c|c|c|c|c|c|c|c|}
\hline & All Assets & REITs & Direct RE & Other RA & Internal & External & $\mathrm{FoF}$ \\
\hline \multicolumn{8}{|c|}{ Panel A: Gross returns (percent) } \\
\hline \multirow[t]{2}{*}{ All funds } & 7.00 & 10.92 & 6.70 & 9.99 & 7.77 & 6.82 & 6.72 \\
\hline & {$[9.41]$} & {$[10.21]$} & {$[8.40]$} & {$[18.57]$} & {$[11.20]$} & {$[9.17]$} & {$[7.85]$} \\
\hline \multicolumn{8}{|c|}{ Panel B: Gross benchmark-adjusted returns (percent) } \\
\hline \multirow[t]{3}{*}{ All funds } & 392 / 3136 & $107 / 703$ & 373 / 3004 & $24 / 143$ & $83 / 686$ & 346 / 2624 & $8 / 55$ \\
\hline & -0.10 & $1.13^{* *}$ & -0.18 & 2.31 & $1.08^{* *}$ & -0.20 & -1.71 \\
\hline & {$[0.26]$} & {$[0.52]$} & {$[0.30]$} & {$[2.27]$} & {$[0.49]$} & {$[0.31]$} & {$[3.21]$} \\
\hline \multirow[t]{3}{*}{ U.S. } & 248 / 1967 & 76 / 491 & 232 / 1872 & $14 / 83$ & $25 / 198$ & 234 / 1833 & $5 / 46$ \\
\hline & -0.38 & 1.06 & -0.47 & 1.67 & 0.47 & -0.38 & $-2.08^{* *}$ \\
\hline & {$[0.34]$} & {$[0.67]$} & {$[0.40]$} & {$[3.01]$} & {$[0.90]$} & {$[0.38]$} & {$[0.91]$} \\
\hline \multirow[t]{3}{*}{ Canada } & $109 / 955$ & $10 / 75$ & $106 / 918$ & $6 / 47$ & 43 / 386 & 83 / 626 & - \\
\hline & 0.40 & 1.92 & 0.31 & 5.60 & $1.20^{*}$ & 0.28 & - \\
\hline & {$[0.50]$} & {$[1.48]$} & {$[0.50]$} & {$[5.49]$} & {$[0.72]$} & {$[0.61]$} & - \\
\hline \multirow[t]{3}{*}{ Europe } & $26 / 173$ & 16 / 114 & $26 / 171$ & $4 / 13$ & $14 / 99$ & $21 / 127$ & - \\
\hline & 0.42 & 1.56 & 0.40 & -0.31 & $1.75^{* *}$ & -0.25 & - \\
\hline & {$[0.75]$} & [1.23] & [1.10] & {$[2.10]$} & {$[0.89]$} & {$[1.43]$} & - \\
\hline \multirow[t]{3}{*}{ Aus/Nzd } & $9 / 41$ & $5 / 23$ & $9 / 43$ & - & - & $8 / 38$ & - \\
\hline & 0.02 & -0.06 & -0.04 & - & - & 0.14 & - \\
\hline & {$[1.45]$} & {$[0.35]$} & {$[1.58]$} & - & - & {$[1.64]$} & - \\
\hline \multicolumn{8}{|c|}{ Panel C: Net benchmark-adjusted returns (percent) } \\
\hline \multirow[t]{3}{*}{ All funds } & $392 / 3136$ & $107 / 703$ & 373 / 3004 & $24 / 143$ & $83 / 686$ & 346 / 2624 & $8 / 55$ \\
\hline & $-0.86^{* * *}$ & 0.70 & $-0.98^{* * *}$ & 1.82 & $0.81^{*}$ & $-1.05^{* * *}$ & -3.90 \\
\hline & {$[0.27]$} & {$[0.52]$} & {$[0.30]$} & {$[2.28]$} & {$[0.49]$} & {$[0.32]$} & [3.39] \\
\hline \multirow[t]{3}{*}{ U.S. } & 248 / 1967 & 76 / 491 & 232 / 1872 & $14 / 83$ & $25 / 198$ & 234 / 1833 & $5 / 46$ \\
\hline & $-1.27^{* * *}$ & 0.56 & $-1.43^{* * *}$ & 1.09 & 0.21 & $-1.29^{* * *}$ & $-3.76^{* * *}$ \\
\hline & {$[0.35]$} & {$[0.66]$} & {$[0.41]$} & {$[3.02]$} & {$[0.90]$} & {$[0.39]$} & {$[0.92]$} \\
\hline \multirow[t]{3}{*}{ Canada } & $109 / 955$ & $10 / 75$ & 106 / 918 & $6 / 47$ & $43 / 386$ & 83 / 626 & - \\
\hline & -0.17 & 1.59 & -0.28 & 5.29 & 0.89 & -0.45 & - \\
\hline & {$[0.51]$} & {$[1.52]$} & {$[0.51]$} & {$[5.46]$} & {$[0.72]$} & {$[0.62]$} & - \\
\hline \multirow[t]{3}{*}{ Europe } & $26 / 173$ & $16 / 114$ & $26 / 171$ & $4 / 13$ & $14 / 99$ & $21 / 127$ & - \\
\hline & 0.00 & 1.33 & -0.10 & -0.59 & $1.55^{*}$ & -0.98 & - \\
\hline & {$[0.78]$} & {$[1.23]$} & {$[1.12]$} & {$[1.75]$} & {$[0.90]$} & {$[1.45]$} & - \\
\hline \multirow[t]{3}{*}{ Aus/Nzd } & $9 / 41$ & $5 / 23$ & $9 / 43$ & - & - & $8 / 38$ & - \\
\hline & -0.41 & -0.31 & -0.59 & - & - & -0.30 & - \\
\hline & {$[1.47]$} & {$[0.33]$} & [1.61] & - & - & {$[1.66]$} & - \\
\hline
\end{tabular}




\section{Table 9: Performance and characteristics}

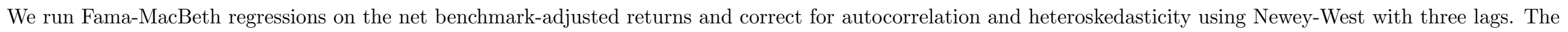

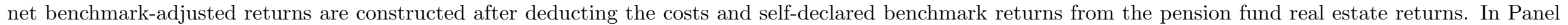

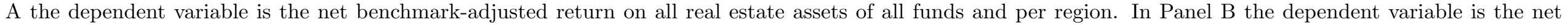

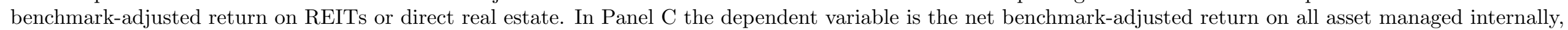

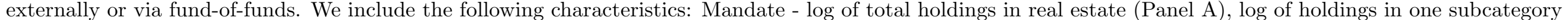

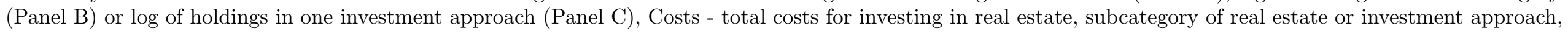

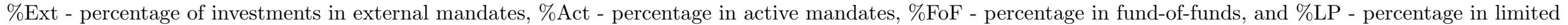
partnerships. We report standard errors in brackets and significance levels with ${ }^{*},{ }^{* *}$ and ${ }^{* * *}$, which correspond to $0.10,0.05$ and 0.01 , respectively.

\begin{tabular}{|c|c|c|c|c|c|c|c|c|c|c|c|c|}
\hline & Model 1 & & Model 2 & & Model 3 & & & & & & & \# Funds \\
\hline & Cons. & Mandate & Cons. & Costs & Cons. & Mandate & Costs & $\%$ Ext & $\%$ Act & $\% \mathrm{FoF}$ & $\% \mathrm{LP}$ & \# Obs. \\
\hline \multicolumn{13}{|c|}{ Panel A: Performance and characteristics for all funds and by region } \\
\hline \multirow[t]{2}{*}{ All funds } & $-2.51^{* * *}$ & $0.43^{* * *}$ & 0.65 & $-1.55^{* * *}$ & -0.28 & $0.32^{* *}$ & $-1.03^{* * *}$ & $-1.02 * *$ & & $-2.02^{* * *}$ & & 634 \\
\hline & [0.37] & {$[0.12]$} & {$[0.63]$} & {$[0.32]$} & {$[0.97]$} & {$[0.15]$} & {$[0.36]$} & {$[0.48]$} & & [0.69] & & 3463 \\
\hline \multirow[t]{2}{*}{ U.S. } & $-3.28 * * *$ & $0.46^{* * *}$ & 0.34 & $-1.43^{* *}$ & $-2.27^{*}$ & $0.40^{* *}$ & -0.66 & -0.10 & & -0.38 & & 391 \\
\hline & {$[0.59]$} & {$[0.17]$} & {$[0.98]$} & {$[0.73]$} & {$[1.30]$} & {$[0.20]$} & [1.01] & {$[0.50]$} & & {$[0.99]$} & & 2156 \\
\hline \multirow[t]{2}{*}{ Canada } & $-2.69 * * *$ & $0.78^{* * *}$ & $1.44^{*}$ & $-2.52^{* * *}$ & -0.70 & $0.59 * * *$ & $-1.74^{* * *}$ & -0.40 & & 3.17 & & 154 \\
\hline & {$[0.97]$} & {$[0.15]$} & {$[0.80]$} & {$[0.58]$} & {$[1.42]$} & {$[0.20]$} & {$[0.66]$} & {$[0.32]$} & & {$[3.08]$} & & 1019 \\
\hline \multirow[t]{2}{*}{ Europe } & 3.31 & -0.27 & $2.70^{* * *}$ & $-5.19 * *$ & $-4.49^{*}$ & $1.05^{* *}$ & -6.16 & -0.45 & & 0.66 & & 73 \\
\hline & {$[4.43]$} & {$[0.57]$} & {$[0.77]$} & {$[2.19]$} & {$[2.34]$} & {$[0.41]$} & {$[5.20]$} & {$[1.07]$} & & {$[0.87]$} & & 237 \\
\hline \multirow[t]{2}{*}{ Aus/Nzd } & -6.25 & 1.16 & -1.98 & 4.16 & -3.47 & 0.18 & 5.29 & - & & - & & 16 \\
\hline & {$[8.25]$} & {$[1.48]$} & {$[2.90]$} & {$[6.17]$} & {$[4.83]$} & {$[0.33]$} & {$[7.74]$} & - & & - & & 48 \\
\hline \multicolumn{13}{|c|}{ Panel B: Performance and characteristics by real estate subcategory } \\
\hline \multirow[t]{2}{*}{ REITs } & $-1.63^{*}$ & 0.39 & -0.11 & 0.69 & $-6.38^{*}$ & $0.70^{* *}$ & 0.13 & 2.42 & 1.61 & & & 199 \\
\hline & {$[0.94]$} & {$[0.25]$} & [1.28] & {$[1.37]$} & {$[3.21]$} & {$[0.32]$} & {$[1.22]$} & {$[1.47]$} & {$[1.57]$} & & & 802 \\
\hline \multirow[t]{2}{*}{ Direct RE } & $-2.55^{* * *}$ & $0.42^{* * *}$ & 0.58 & $-1.50 * * *$ & -0.02 & $0.31^{* * *}$ & $-1.11 * * *$ & $-1.22^{* *}$ & & $-2.63^{* * *}$ & 1.00 & 608 \\
\hline & {$[0.54]$} & {$[0.09]$} & {$[0.69]$} & {$[0.24]$} & [1.05] & {$[0.12]$} & {$[0.34]$} & {$[0.56]$} & & {$[0.78]$} & {$[1.50]$} & 3324 \\
\hline \multicolumn{13}{|c|}{ Panel C: Performance and characteristics by investment approach } \\
\hline \multirow[t]{2}{*}{ Internal } & -1.18 & $0.43^{*}$ & $1.89^{* *}$ & -3.70 & -0.71 & 0.43 & -2.56 & & & & & 141 \\
\hline & {$[1.37]$} & {$[0.26]$} & {$[0.95]$} & {$[2.70]$} & [2.09] & {$[0.28]$} & {$[2.96]$} & & & & & 761 \\
\hline \multirow[t]{2}{*}{ External } & $-2.29 * * *$ & $0.35^{* * *}$ & 0.37 & $-1.33^{* * *}$ & -1.07 & $0.30^{* *}$ & $-1.13^{* * *}$ & & & & & 580 \\
\hline & {$[0.41]$} & {$[0.13]$} & {$[0.68]$} & {$[0.35]$} & {$[0.70]$} & {$[0.14]$} & {$[0.41]$} & & & & & 2937 \\
\hline \multirow{2}{*}{ FoF } & 1.48 & -1.96 & -4.35 & -0.78 & 4.92 & -2.16 & -1.05 & & & & & 29 \\
\hline & {$[4.94]$} & {$[2.02]$} & {$[5.52]$} & {$[4.24]$} & [15.84] & {$[2.50]$} & {$[4.58]$} & & & & & 53 \\
\hline
\end{tabular}




\section{Table 10: Persistence in pension fund real estate performance}

Pension funds are placed into quintiles based on their total net benchmark-adjusted returns (Panel A), direct real estate returns (Panels B and C) and REIT returns (Panel D). High row or column represents the quintile with the highest return. Percentages represent the probability that a fund which was ranked in one of the 5 quintiles in year $t$ ends up in one of the quintiles in year $(t+1)$. Return in $(t+1)$ columns present the total, direct real estate and REIT returns in year $(t+1)$ of the top and bottom quintiles, which are formed in year $t$. The Test Diff column is a t-statistic of the difference in returns between the low and high quintile. The REIT performance quintiles and Test in Panel D are based on the 1998-2009 period, whereas in the other panels we employ the entire sample period. In Panel $\mathrm{C}$ for direct real estate we look at the persistence over a two-year horizon to control for possible short term smoothing of the returns.

\begin{tabular}{|c|c|c|c|c|c|c|c|c|c|}
\hline \multicolumn{10}{|c|}{ Panel A: All real estate } \\
\hline & & \multicolumn{5}{|c|}{ Year $(t+1)$ ranking } & \multicolumn{2}{|c|}{ Return in $(t+1)$} & \multirow{2}{*}{$\begin{array}{l}\text { Test } \\
\text { Diff }\end{array}$} \\
\hline & & Low & 2 & 3 & 4 & High & Low & High & \\
\hline \multirow{5}{*}{ Year $t$ ranking } & Low & $34.10 \%$ & $22.04 \%$ & $16.01 \%$ & $12.89 \%$ & $14.97 \%$ & \multirow[t]{5}{*}{-2.95} & \multirow[t]{5}{*}{1.31} & \multirow[t]{5}{*}{5.89} \\
\hline & 2 & $22.11 \%$ & $27.01 \%$ & $23.09 \%$ & $14.48 \%$ & $13.31 \%$ & & & \\
\hline & 3 & $15.54 \%$ & $20.12 \%$ & $29.08 \%$ & $21.31 \%$ & $13.94 \%$ & & & \\
\hline & 4 & $12.14 \%$ & $15.61 \%$ & $16.38 \%$ & $31.98 \%$ & $23.89 \%$ & & & \\
\hline & High & $16.57 \%$ & $12.48 \%$ & $11.70 \%$ & $20.66 \%$ & $38.60 \%$ & & & \\
\hline
\end{tabular}

Panel B: Direct real estate (one-year persistence)

\begin{tabular}{|c|c|c|c|c|c|c|c|c|c|}
\hline & & \multicolumn{5}{|c|}{ Year $(t+1)$ ranking } & \multicolumn{2}{|c|}{ Return in $(t+1)$} & \multirow{2}{*}{$\begin{array}{l}\text { Test } \\
\text { Diff }\end{array}$} \\
\hline & & Low & 2 & 3 & 4 & High & Low & High & \\
\hline \multirow{5}{*}{ Year $t$ ranking } & Low & $34.30 \%$ & $22.11 \%$ & $16.94 \%$ & $13.84 \%$ & $12.81 \%$ & \multirow[t]{5}{*}{-3.26} & \multirow[t]{5}{*}{1.56} & \multirow[t]{5}{*}{6.23} \\
\hline & 2 & $19.80 \%$ & $27.96 \%$ & $23.06 \%$ & $15.10 \%$ & $14.08 \%$ & & & \\
\hline & 3 & $15.43 \%$ & $20.04 \%$ & $26.65 \%$ & $22.44 \%$ & $15.43 \%$ & & & \\
\hline & 4 & $13.43 \%$ & $15.70 \%$ & $17.98 \%$ & $29.75 \%$ & $23.14 \%$ & & & \\
\hline & High & $15.34 \%$ & $12.55 \%$ & $12.75 \%$ & $20.32 \%$ & $39.04 \%$ & & & \\
\hline
\end{tabular}

Panel C: Direct real estate (two-years persistence)

\begin{tabular}{|c|c|c|c|c|c|c|c|c|c|}
\hline & & \multicolumn{5}{|c|}{ Year $(t+2)$ ranking } & \multicolumn{2}{|c|}{ Return in $(t+2)$} & \multirow{2}{*}{$\begin{array}{l}\text { Test } \\
\text { Diff }\end{array}$} \\
\hline & & Low & 2 & 3 & 4 & High & Low & High & \\
\hline \multirow{5}{*}{ Year $t$ ranking } & Low & $26.24 \%$ & $20.44 \%$ & $17.13 \%$ & $16.85 \%$ & $19.34 \%$ & \multirow[t]{5}{*}{-1.43} & \multirow[t]{5}{*}{0.55} & \multirow[t]{5}{*}{2.46} \\
\hline & 2 & $20.16 \%$ & $26.26 \%$ & $20.69 \%$ & $18.04 \%$ & $14.85 \%$ & & & \\
\hline & 3 & $13.40 \%$ & $19.60 \%$ & $27.79 \%$ & $23.33 \%$ & $15.88 \%$ & & & \\
\hline & 4 & $16.71 \%$ & $17.72 \%$ & $18.73 \%$ & $24.81 \%$ & $22.03 \%$ & & & \\
\hline & High & $18.30 \%$ & $16.54 \%$ & $15.54 \%$ & $19.80 \%$ & $29.82 \%$ & & & \\
\hline
\end{tabular}

Panel D: REITs (1998-2009 period)

\begin{tabular}{|c|c|c|c|c|c|c|c|c|c|}
\hline & & \multicolumn{5}{|c|}{ Year $(t+1)$ ranking } & \multicolumn{2}{|c|}{ Return in $(t+1)$} & \multirow{2}{*}{$\begin{array}{l}\text { Test } \\
\text { Diff }\end{array}$} \\
\hline & & Low & 2 & 3 & 4 & High & Low & High & \\
\hline \multirow{5}{*}{ Year $t$ ranking } & Low & $30.36 \%$ & $13.39 \%$ & $15.18 \%$ & $21.43 \%$ & $19.64 \%$ & \multirow[t]{5}{*}{-0.56} & \multirow[t]{5}{*}{-0.35} & \multirow[t]{5}{*}{0.13} \\
\hline & 2 & $16.04 \%$ & $31.13 \%$ & $29.25 \%$ & $14.15 \%$ & $9.43 \%$ & & & \\
\hline & 3 & $13.16 \%$ & $28.07 \%$ & $18.42 \%$ & $24.56 \%$ & $15.79 \%$ & & & \\
\hline & 4 & $15.97 \%$ & $10.92 \%$ & $25.21 \%$ & $30.25 \%$ & $17.65 \%$ & & & \\
\hline & High & $31.19 \%$ & $12.84 \%$ & $16.51 \%$ & $14.68 \%$ & $24.77 \%$ & & & \\
\hline
\end{tabular}


Figure 1: How pension funds invest in real estate: the institutional marketplace and the investment process

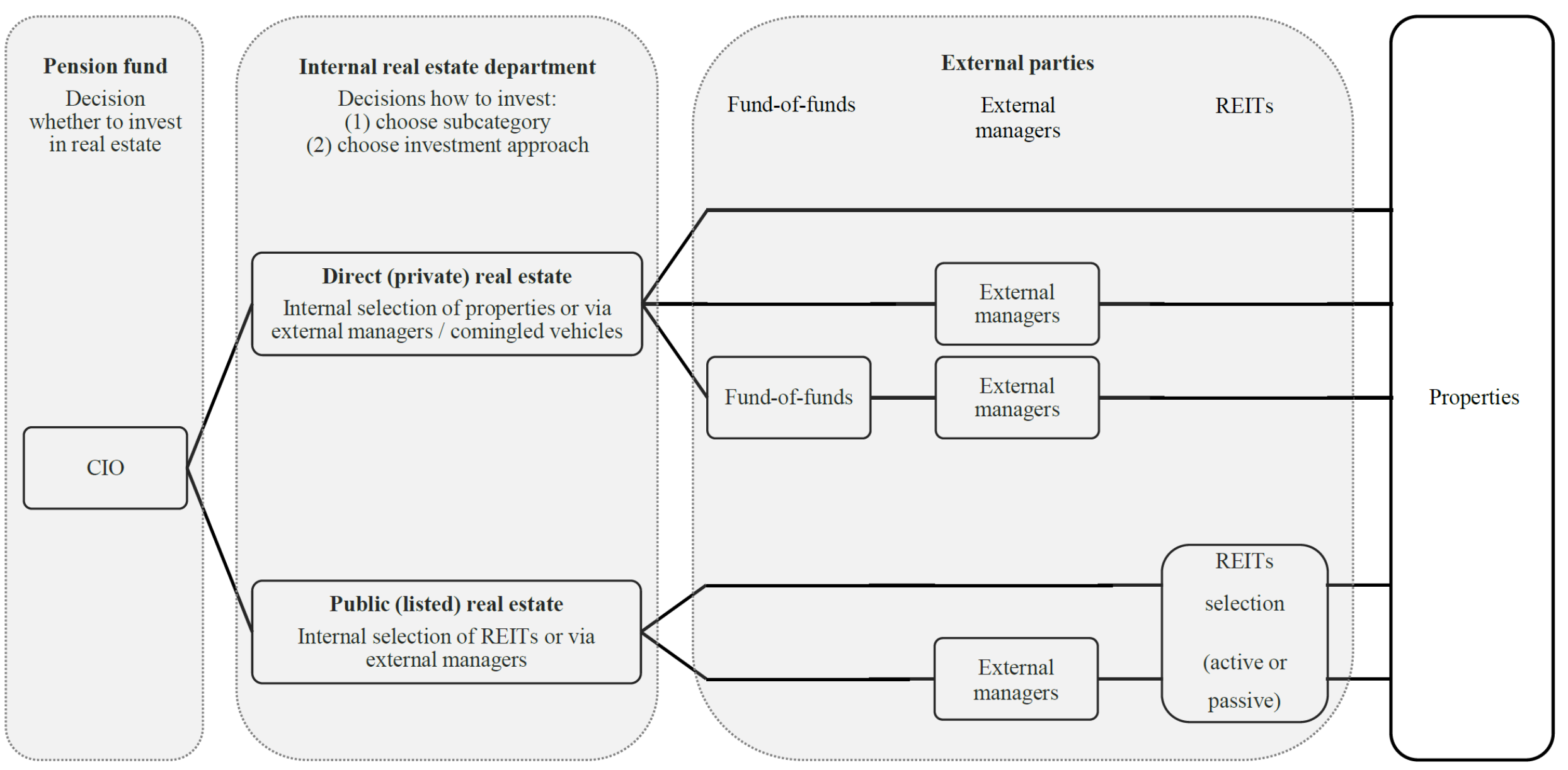


Figure 2: Pension fund real estate investments

Panel A: Percentage of funds investing in real estate

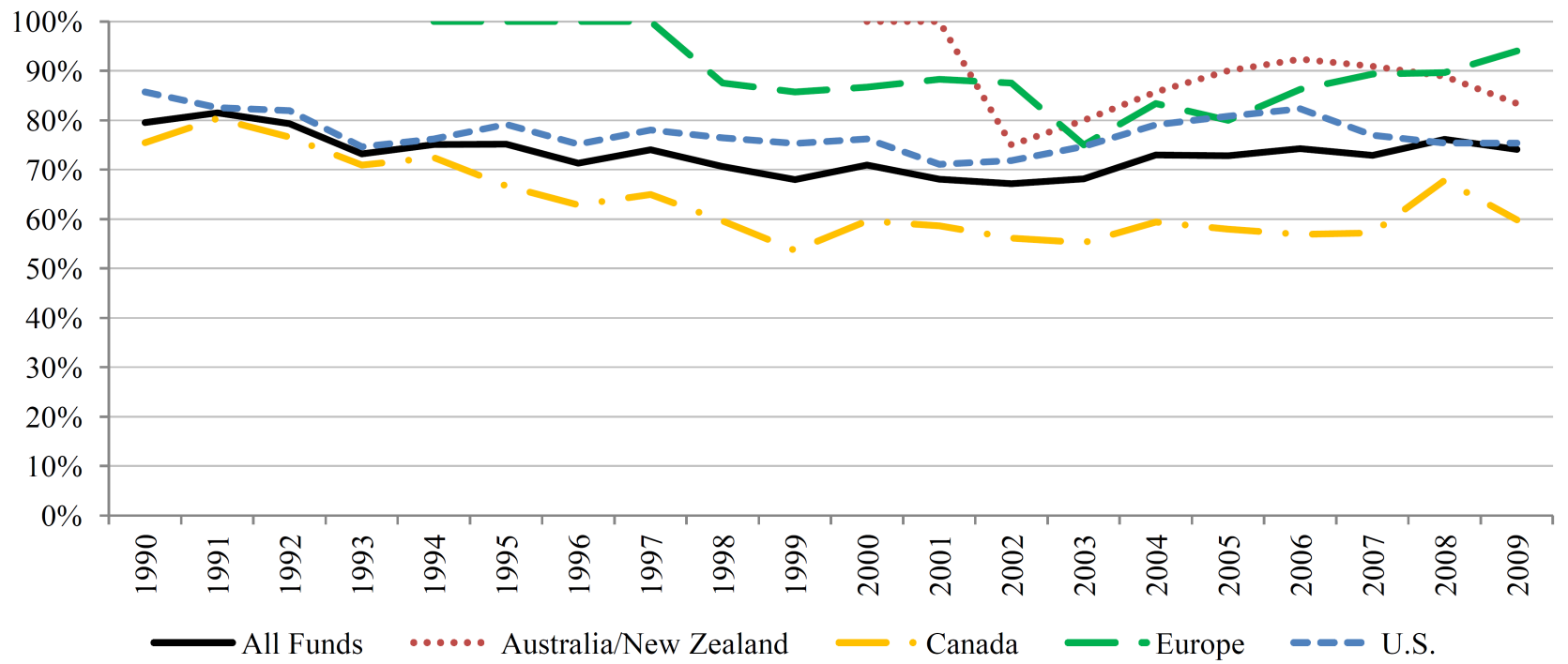

Panel B: Total pension fund investments in real estate (in billion US\$)

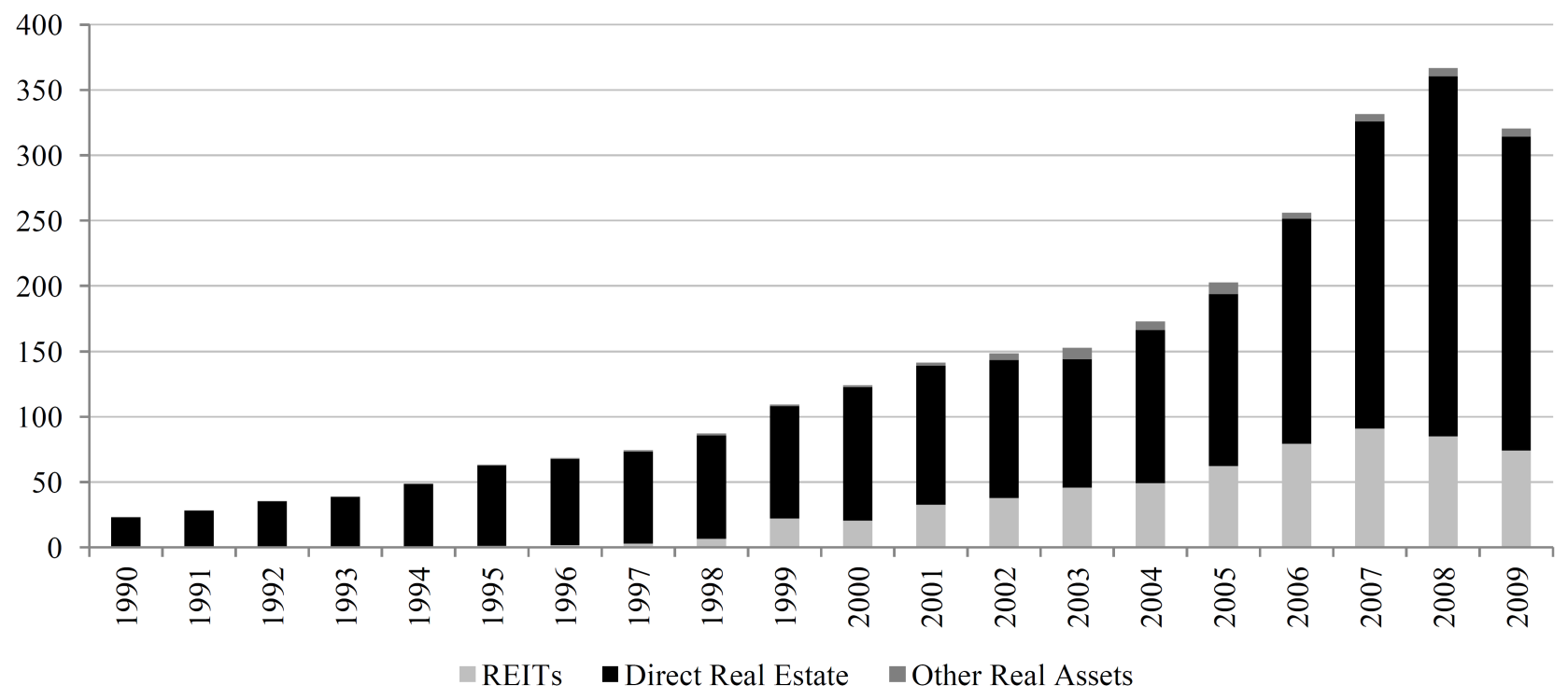

Panel C: Real estate as a percentage of total pension fund assets

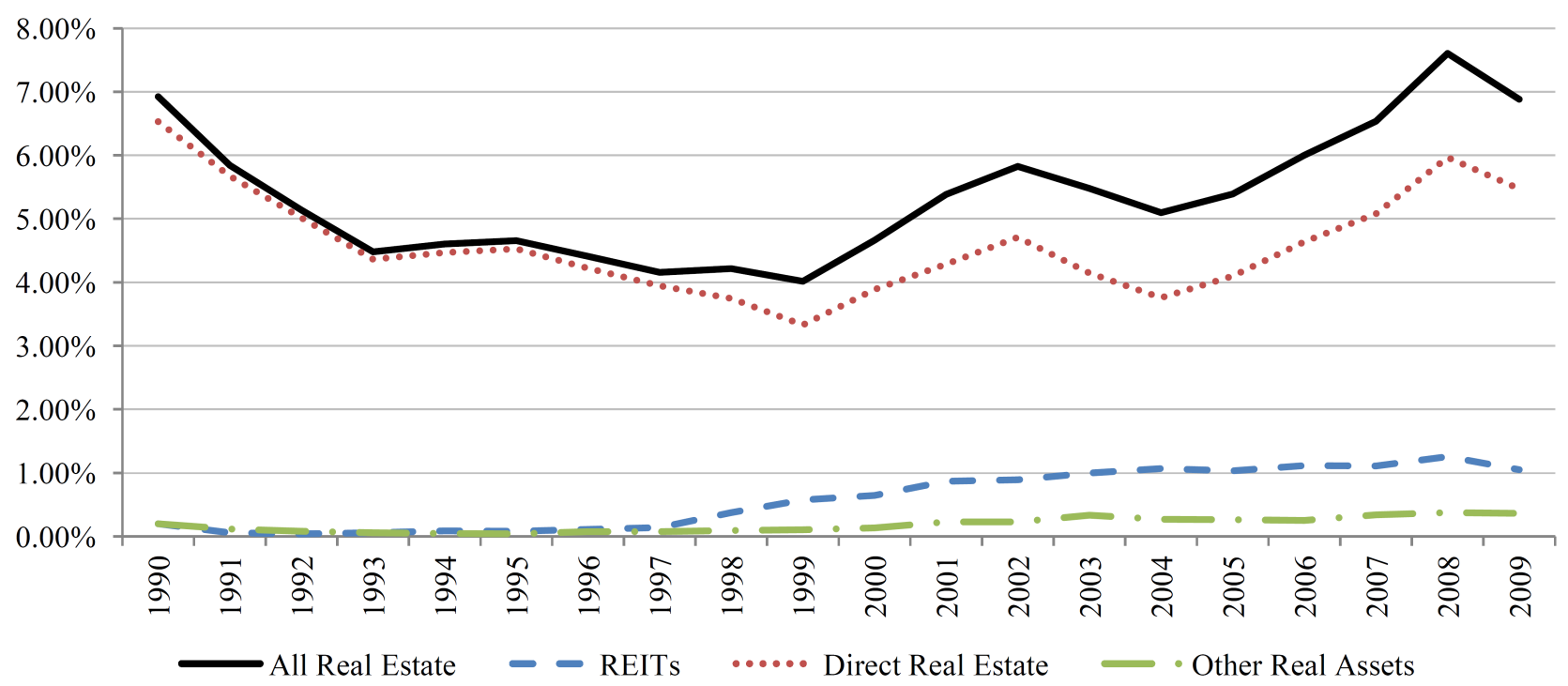


Figure 3: Percentage of pension funds investing in real estate subcategories

Panel A: Percentage of funds investing in REITs

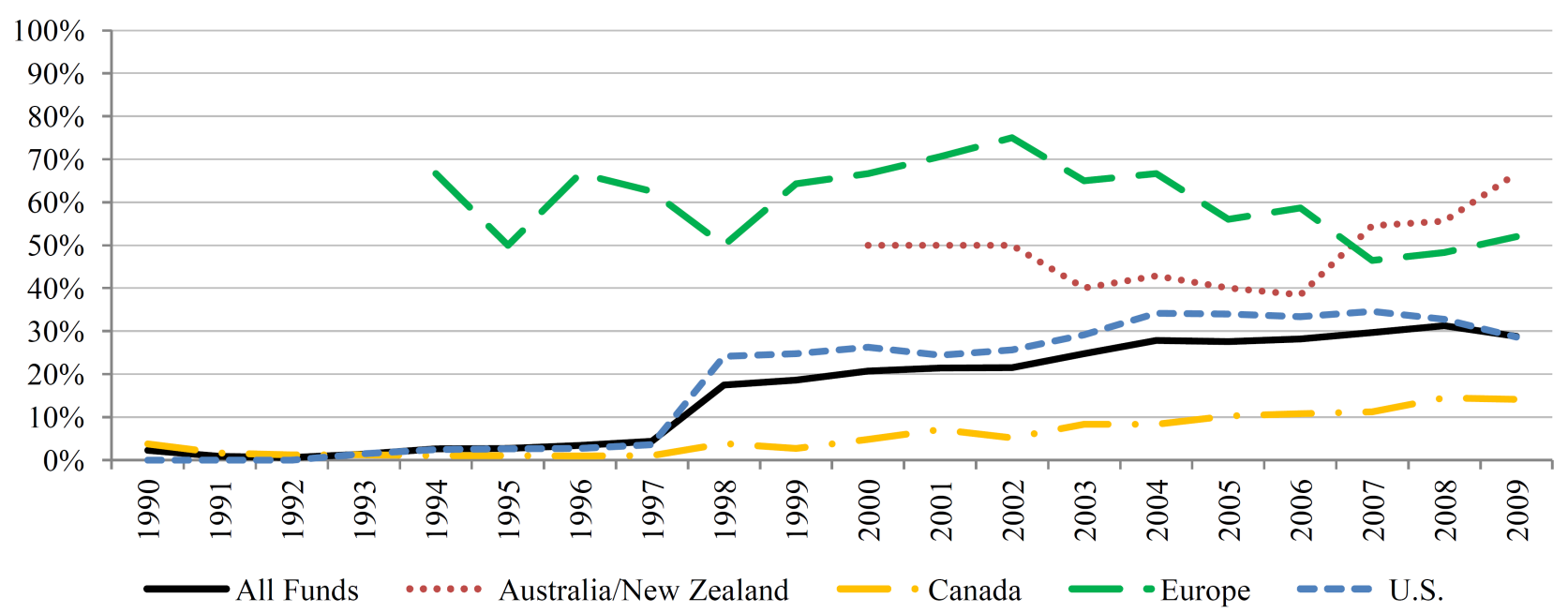

Panel B: Percentage of funds investing in direct real estate

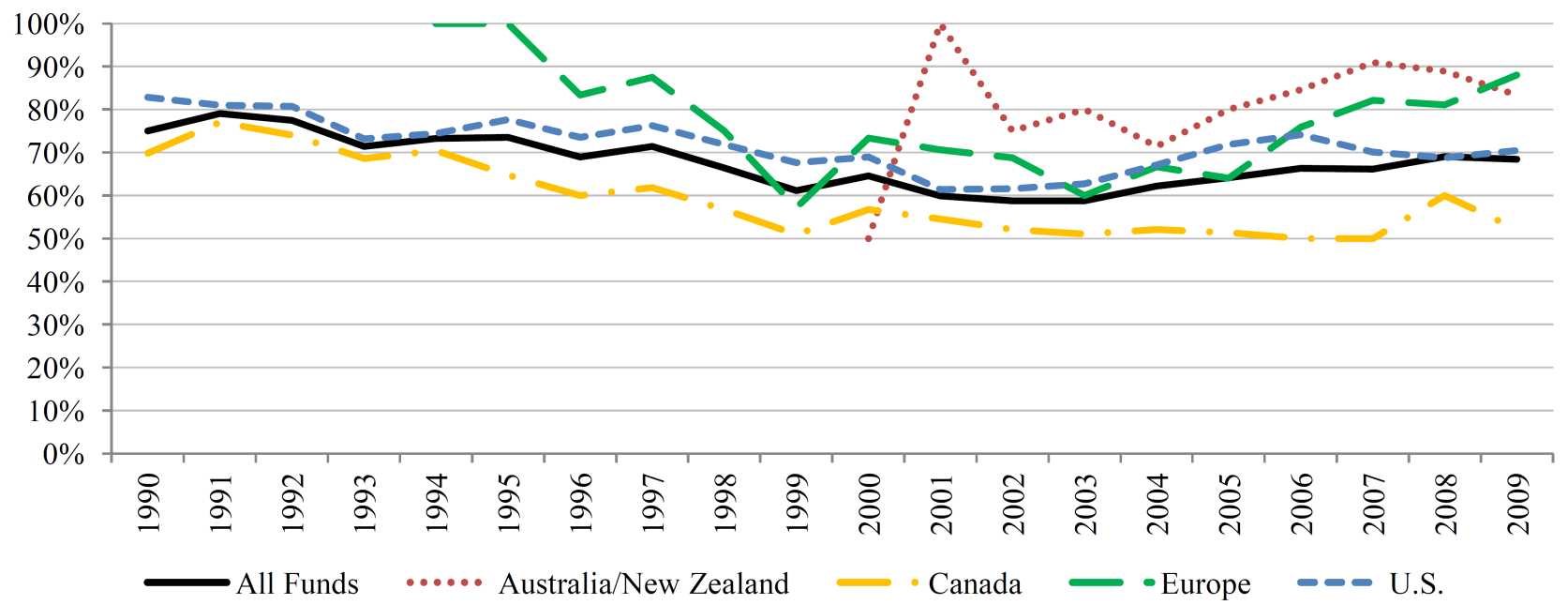


Figure 4: Time trend in allocations to real estate subcategories and investment approaches Panel A: Average pension fund investments in real estate subcategories

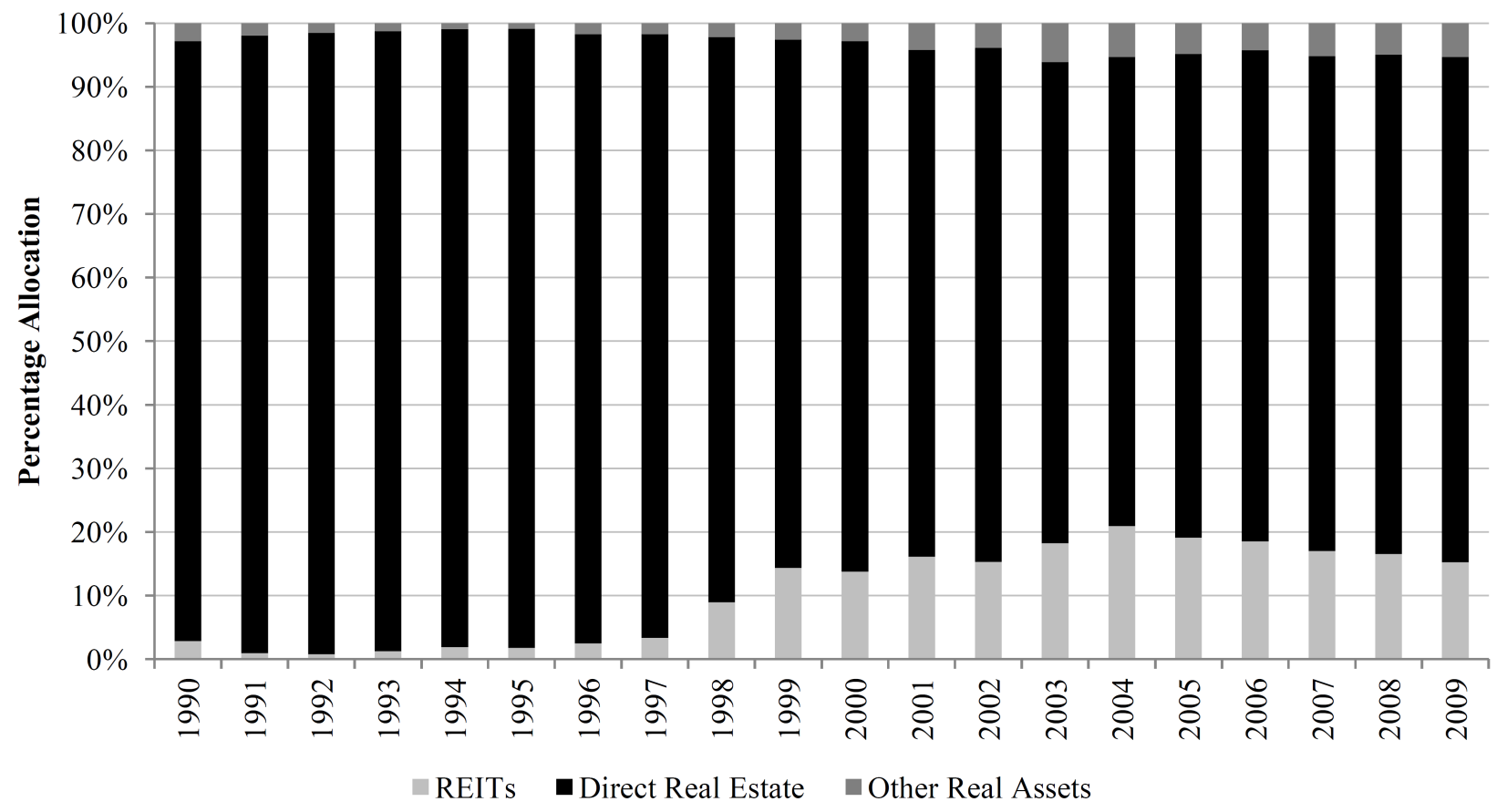

Panel B: Average percentage of assets allocated to an investment approach

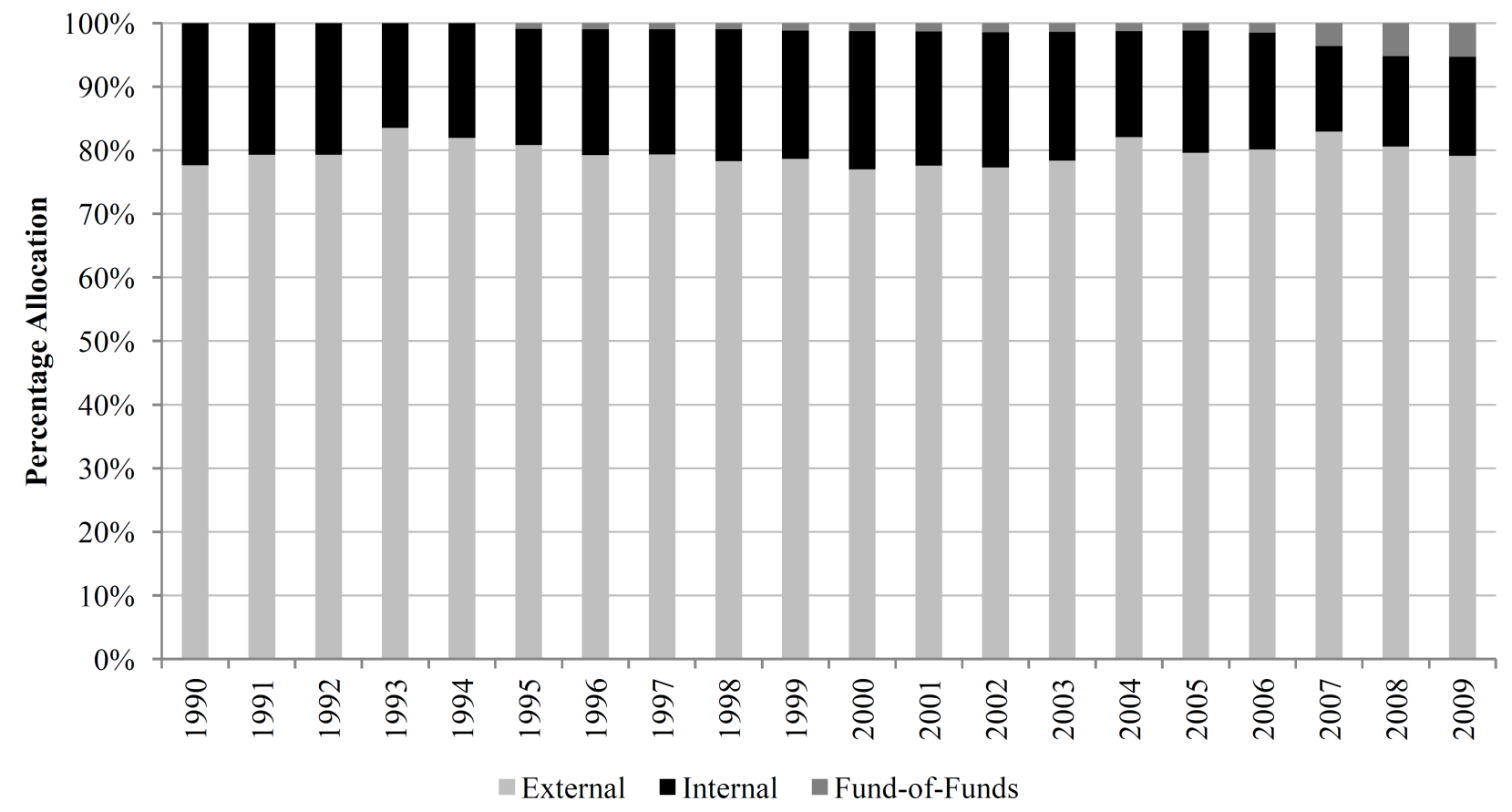


Figure 5: Real estate investment costs by region and subcategory

Panel A: Overall real estate costs in basis points by region

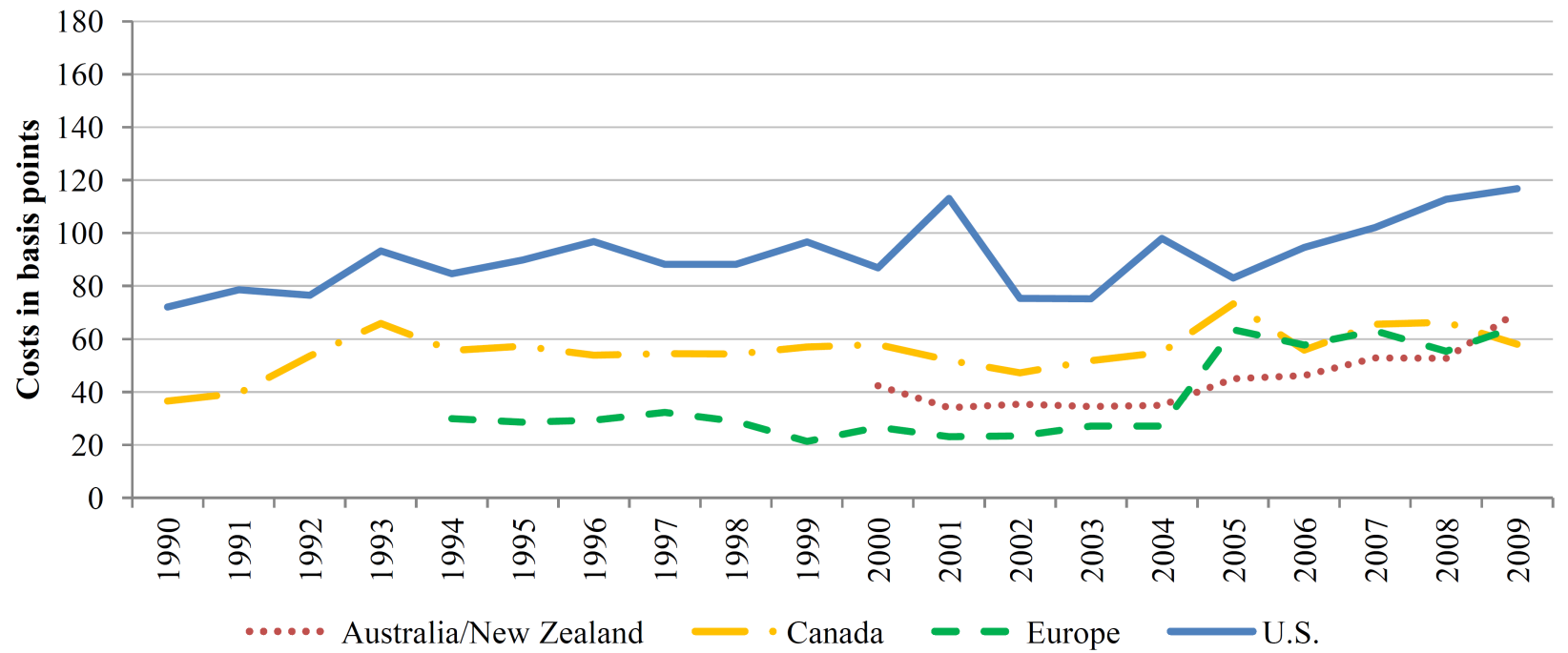

Panel B: Costs to invest in REITs (basis points)

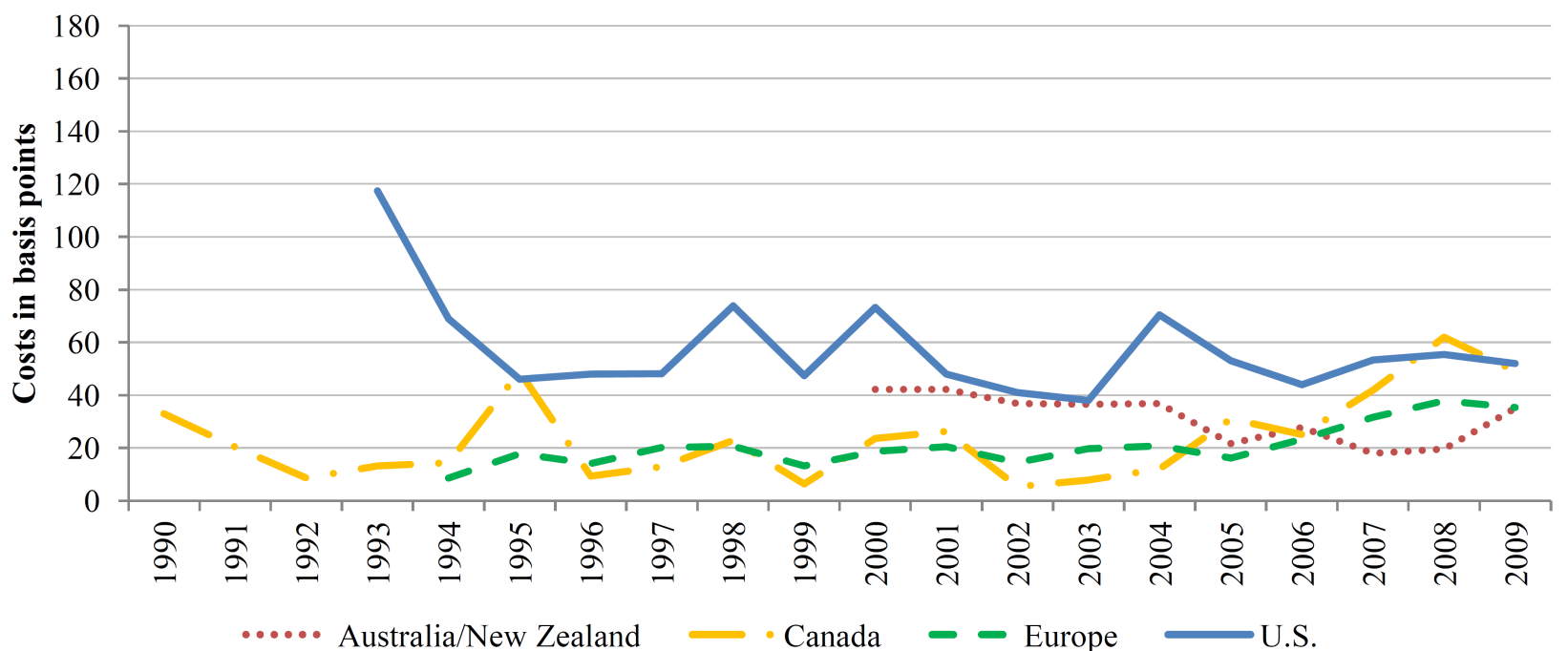

Panel C: Costs to invest in direct real estate (basis points)

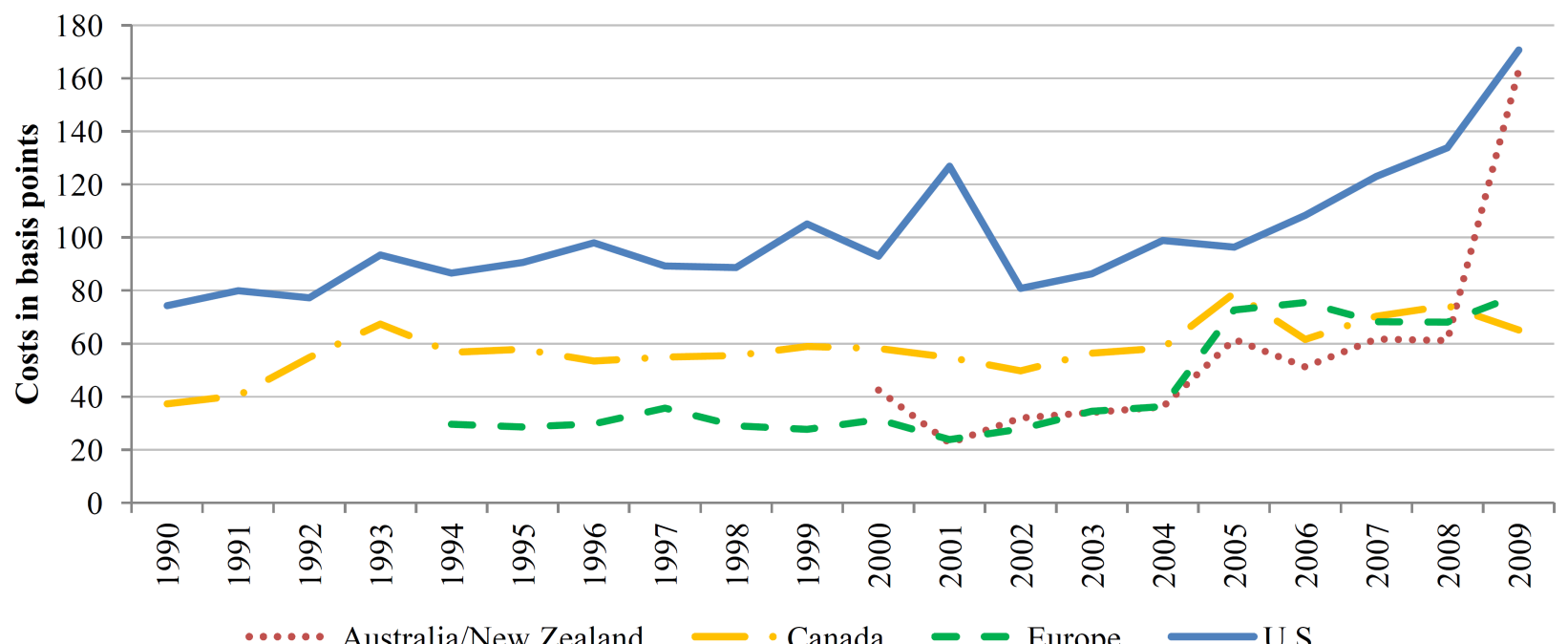


Figure 6: Performance of U.S. funds in direct real estate

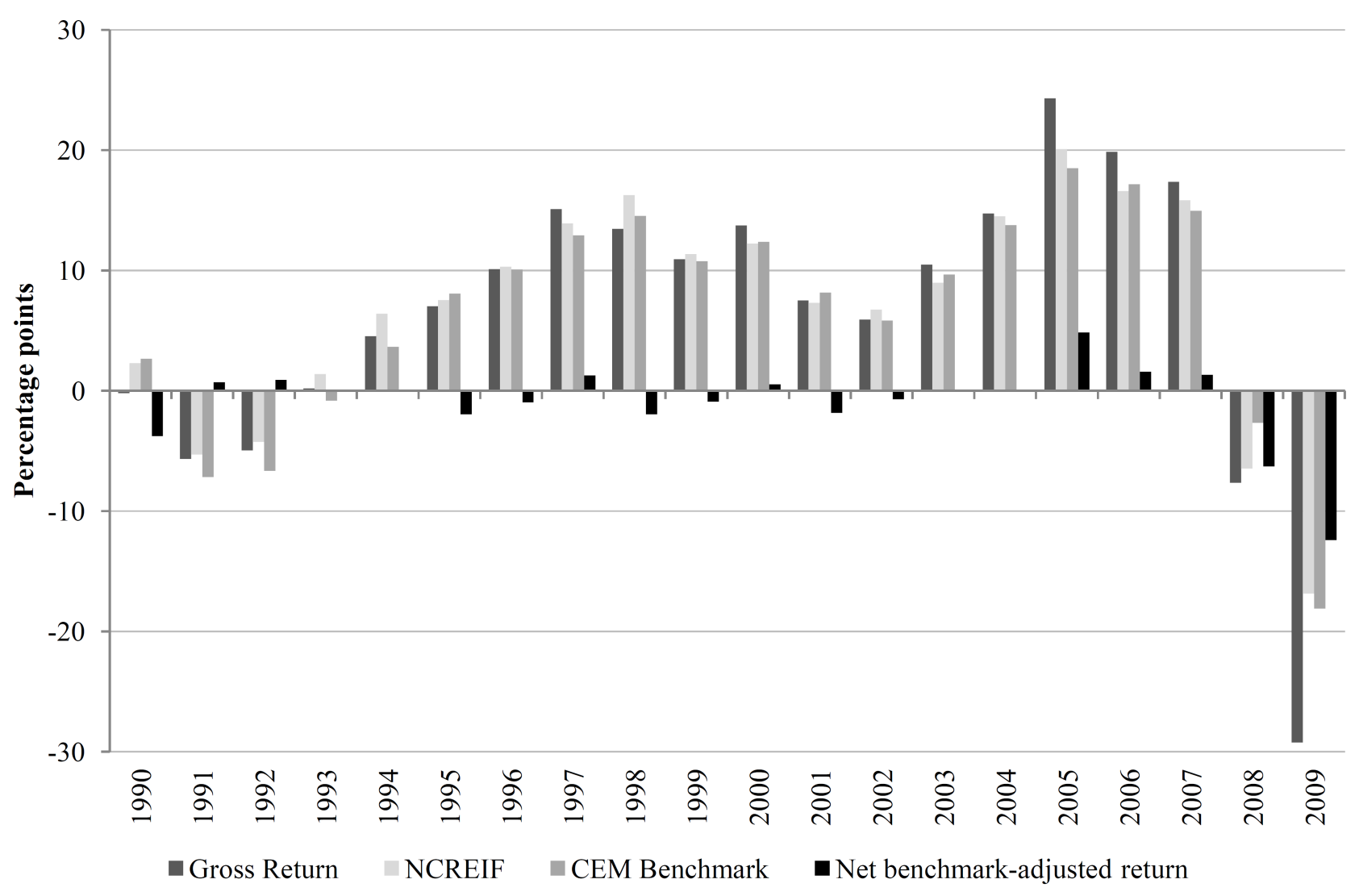


Table A.1: Performance and characteristics 1990-2007 (Appendix of Table 9)

We run Fama-MacBeth regressions on the net benchmark-adjusted returns and correct for autocorrelation and heteroskedasticity using Newey-West with three lags. The net benchmark-adjusted returns are constructed after deducting the costs and self-declared benchmark returns from the pension fund real estate returns. In Panel A the dependent variable is the net benchmark-adjusted return on all real estate assets of all funds and per region. In Panel B the dependent variable is the net benchmark-adjusted return on REITs or direct real estate. In Panel C the dependent variable is the net benchmark-adjusted return on all asset managed internally, externally or via fund-of-funds. We include the following characteristics: Mandate - log of total holdings in real estate (Panel A), log of holdings in one subcategory (Panel B) or log of holdings in one investment approach (Panel C), Costs - total costs for investing in real estate, subcategory of real estate or investment approach, \%Ext - percentage of investments in external mandates, \%Act - percentage in active mandates, \%FoF - percentage in fund-of-funds, and \%LP - percentage in limited partnerships. We report standard errors in brackets and significance levels with *, ${ }^{*}$ and ${ }^{* * *}$, which correspond to $0.10,0.05$ and 0.01 , respectively.

\begin{tabular}{|c|c|c|c|c|c|c|c|c|c|c|c|c|}
\hline & Model 1 & & Model 2 & & Model 3 & & & & & & & \# Funds \\
\hline & Cons. & Mandate & Cons. & Costs & Cons. & Mandate & Costs & $\% \mathrm{Ext}$ & $\%$ Act & $\% \mathrm{FoF}$ & $\% \mathrm{LP}$ & \# Obs. \\
\hline \multicolumn{13}{|c|}{ Panel A: Performance and characteristics for all funds and by region } \\
\hline All funds & $\begin{array}{c}-2.35^{* * *} \\
{[0.42]}\end{array}$ & $\begin{array}{c}0.52^{* * *} \\
{[0.10]}\end{array}$ & $\begin{array}{c}1.04 \\
\lceil 0.69]\end{array}$ & $\begin{array}{c}-1.35 * * * \\
{[0.29]}\end{array}$ & $\begin{array}{l}-0.78 \\
{[0.77]}\end{array}$ & $\begin{array}{c}0.45^{* * *} \\
{[0.09]}\end{array}$ & $\begin{array}{c}-0.75 * * \\
{[0.30]}\end{array}$ & $\begin{array}{c}-0.79 * * \\
{[0.37]}\end{array}$ & & $\begin{array}{c}-2.21^{* * * *} \\
{[0.80]}\end{array}$ & & $\begin{array}{c}570 \\
2985\end{array}$ \\
\hline \multirow[t]{2}{*}{ U.S. } & $-3.39^{* * *}$ & $0.62^{* * *}$ & 0.90 & $-1.28^{*}$ & $-2.97^{* *}$ & $0.62^{* * *}$ & -0.35 & -0.14 & & -0.88 & & 371 \\
\hline & {$[0.67]$} & {$[0.16]$} & {$[0.99]$} & {$[0.79]$} & {$[1.42]$} & {$[0.17]$} & {$[1.07]$} & {$[0.56]$} & & {$[0.98]$} & & 1876 \\
\hline \multirow[t]{2}{*}{ Canada } & $-2.24^{*}$ & $0.80^{* * *}$ & $1.54^{*}$ & $-1.88^{* * *}$ & -0.90 & $0.67^{* * *}$ & $-0.94^{* *}$ & -0.50 & & 4.54 & & 149 \\
\hline & {$[1.19]$} & {$[0.15]$} & {$[0.91]$} & {$[0.61]$} & [1.39] & {$[0.17]$} & {$[0.48]$} & {$[0.39]$} & & {$[4.50]$} & & 924 \\
\hline \multirow[t]{2}{*}{ Europe } & 4.03 & -0.29 & $2.96^{* * *}$ & $-5.06^{* *}$ & -5.60 & $1.22^{*}$ & -6.08 & -0.32 & & 0.57 & & 35 \\
\hline & {$[5.01]$} & {$[0.65]$} & {$[0.80]$} & {$[2.56]$} & {$[4.69]$} & {$[0.61]$} & {$[5.05]$} & [1.44] & & {$[1.89]$} & & 146 \\
\hline \multirow{2}{*}{ Aus/Nzd } & -6.92 & 1.51 & -1.32 & 4.16 & -1.96 & -0.03 & 7.66 & - & & - & & 15 \\
\hline & {$[10.18]$} & {$[1.86]$} & [4.63] & {$[6.17]$} & [6.13] & {$[0.48]$} & {$[9.72]$} & - & & - & & 36 \\
\hline \multicolumn{13}{|c|}{ Panel B: Performance and characteristics by real estate subcategory } \\
\hline \multirow[t]{2}{*}{ REITs } & $-2.54^{* *}$ & $0.61^{* *}$ & 0.31 & 0.11 & $-7.08^{*}$ & $0.87^{* *}$ & -0.40 & 2.26 & 2.10 & & & 166 \\
\hline & {$[1.11]$} & {$[0.30]$} & [1.52] & {$[1.51]$} & {$[3.30]$} & {$[0.36]$} & {$[1.27]$} & {$[1.53]$} & [1.33] & & & 601 \\
\hline \multirow{2}{*}{ Direct RE } & $-2.07 * * *$ & $0.48^{* * *}$ & 1.09 & $-1.32^{* * *}$ & -0.35 & $0.41 * * *$ & $-0.89 * * *$ & $-0.90^{* *}$ & & $-2.67^{* * *}$ & 1.67 & 543 \\
\hline & {$[0.52]$} & {$[0.08]$} & {$[0.71]$} & {$[0.22]$} & {$[1.00]$} & {$[0.08]$} & {$[0.32]$} & {$[0.37]$} & & {$[0.85]$} & {$[1.48]$} & 2869 \\
\hline \multicolumn{13}{|c|}{ Panel C: Performance and characteristics by investment approach } \\
\hline \multirow[t]{2}{*}{ Internal } & -1.79 & $0.60^{* * *}$ & $2.26^{* *}$ & -3.39 & -1.30 & $0.58^{* *}$ & -2.13 & & & & & 130 \\
\hline & {$[1.25]$} & {$[0.22]$} & {$[1.05]$} & {$[2.91]$} & {$[2.18]$} & {$[0.27]$} & [3.18] & & & & & 665 \\
\hline \multirow{2}{*}{ External } & $-2.14^{* * *}$ & $0.46^{* * *}$ & 0.80 & $-1.09 * * *$ & $-1.32^{*}$ & $0.43^{* * *}$ & $-0.86^{* *}$ & & & & & 519 \\
\hline & {$[0.44]$} & {$[0.10]$} & {$[0.70]$} & {$[0.32]$} & {$[0.73]$} & {$[0.10]$} & {$[0.37]$} & & & & & 2520 \\
\hline
\end{tabular}

